\title{
SDU
}

\section{Church Membership and Social Insurance: \\ Evidence from the Great Mississippi Flood of 1927}

by

\author{
Philipp Ager, Casper Worm Hansen and Lars Lønstrup
}

Discussion Papers on Business and Economics

No. 7/2016

FURTHER INFORMATION

Department of Business and Economics Faculty of Business and Social Sciences University of Southern Denmark Campusvej 55, DK-5230 Odense M

Denmark 


\title{
Church Membership and Social Insurance:
}

\section{Evidence from the Great Mississippi Flood of $1927^{*}$}

\author{
Philipp Ager \\ Casper Worm Hansen \\ Lars Lønstrup ${ }^{\dagger}$
}

\begin{abstract}
Religious communities are key providers of social insurance. This paper focuses on the devastating impact of the Great Mississippi Flood of 1927 to investigate how an increase in the demand for social insurance affects church membership. We find a significant increase in church membership in flooded counties. This effect is stronger in counties with severe economic losses and where access to credit was limited. We also document that fundamental denominations gained more members in flooded counties, which is consistent with the theory of club goods emphasizing the efficient provision of mutual insurance in stricter religious communities.
\end{abstract}

Keywords: Religion; Informal Insurance; Club Goods; Natural Disasters.

JEL codes: Z12; H40; D70

${ }^{*}$ Acknowledgements: We would like to thank Thomas Barnebeck Andersen, Sascha O. Becker, Jeanet Bentzen, Stephen Broadberry, Daniel L. Chen, Antonio Ciccone, Carl-Johan Dalgaard, Francesco Drago, Walter Garcia-Fontes, Daniel Hungerman, Peter Sandholt Jensen, Nicolai Kaarsen, Erzo F.P. Luttmer, Paul Sharp, Holger Strulik, Nico Voigtländer, and seminar participants at the Danish Public Choice workshop 2014 (University of Copenhagen), the 5th workshop on Growth, History and Development (University of Southern Denmark), the FRESH meeting at Canterbury (University of Kent), the SAEe 2014 at Palma de Mallorca (Universitat de les Illes Balears), the Historical Economics of Religion Workshop 2015 (Queen's University Belfast), and the ASREC Europe 2016 conference (University of Copenhagen) for their helpful comments and suggestions. The paper was previously entitled "Church Membership and Social Insurance: Evidence from the American South".

${ }^{\dagger}$ Contact: Philipp Ager, University of Southern Denmark; phag@sam.sdu.dk. Casper Worm Hansen, University of Copenhagen; casper.worm.hansen@econ.ku.dk. Lars Lønstrup, University of Southern Denmark; loe@sam.sdu.dk. 


\section{Introduction}

A salient feature of religious communities is their involvement in social services and insurance. ${ }^{1}$ This fact is explained in economic theories that consider religious communities as clubs. The theory of club goods proposes that economic incentives affect religious participation and stresses mutual insurance in religious communities as a central reason for their existence. ${ }^{2}$ In particular, fundamental denominations are regarded as efficient providers of mutual insurance since their strict behavioral restrictions and sacrifices induce participation and prevent group members from free-riding (Iannaccone, 1992; Berman, 2000; Abramitzky, 2008).

This paper provides evidence in line with the theory of club goods predicting that increased demand for social insurance should increase church membership. Our study documents how church membership evolved in the aftermath of the Great Mississippi Flood of 1927. This flood was considered to be one of the greatest natural disasters in the history of the United States (American National Red Cross, 1929). More than 160,000 family homes were flooded in an area where around 930,000 people resided. Property losses of local business and public utilities and the implied suspension of normal business "constituted an economic aftermath beyond computation" (American National Red Cross, 1929, p.7). We test whether this unprecedented shock to the economy of the affected areas increased the demand for social insurance and participation in religious communities. $^{3}$

Our first contribution is to document that the Great Mississippi Flood of 1927 caused an increase in church membership. We exploit time variation due to the flood together with cross-sectional variation in the fraction of county area flooded within the same state using a differences-in-differences framework and show that religious organizations significantly increased their membership numbers in flooded counties relative to non-flooded counties between 1926 and 1936. In particular, flooded counties experienced, on average, a 16 percentage point

\footnotetext{
${ }^{1}$ For studies on the role religious communities play as providers of social services, see Moberg (1984), Cnaan and Boddie (2002), McCleary and Barro (2006a), and Gruber and Hungerman (2007), for example.

${ }^{2}$ See Corners and Sandler (1986) for more details on the theory of club goods.

${ }^{3}$ Out of the massive total losses, the flood destroyed crops and killed livestock with an estimated value of around $\$ 124$ million (1927 prices). For a rough comparison, the GDP for the United States in 1927 was around $\$ 100$ billion and GDP per capita was around $\$ 810$ (Williamson, 2015). This means that the losses in only crops and livestock comprised the yearly income of around 150,000 individuals, which is circa 16 percent of the number of people living in flooded areas.
} 
increase in church members per capita. The key identifying assumptions in a differences-indifferences framework include common pre-treatment trends and no omitted variables which are correlated with the flood intensity during the treatment period. We provide evidence that strongly supports both assumptions.

Our second contribution is to present supporting evidence for the hypothesis that an increase in the demand for social insurance was a central mechanism through which the flood influenced church membership. ${ }^{4}$ If the effect of the flood on church membership works through increased demand for social insurance, it is a necessary condition that the effect on church membership is larger in counties that experienced more severe economic losses due to the flood. Consistent with this condition, we show that the positive effect of the flood on church membership was stronger in counties with higher reported per capita losses and damages resulting from the Great Mississippi Flood of $1927 .{ }^{5}$ We further show that credit availability mitigated the positive effect of the flood on church membership: counties with better credit availability experienced a smaller increase in the flood-induced demand for social insurance provided by local religious communities. These findings suggest that access to the mutual insurance networks of religious communities and credit availability during economic distress played a central role for the decision to become a church member or not.

The Census of Religious Bodies collected data on church membership by county and denomination which allows us to examine whether specific religious denominations accounted for the surge in membership in flooded counties. In this respect, a novel feature of this paper is to document whether stricter (evangelical/fundamental) denominations gained more members in flooded counties. A key characteristic of these denominations is their stricter religious practices. Iannaccone $(1992,1994)$ argues that these stricter denominations are more efficient providers of mutual insurance arrangements, as they efficiently counteract free-riding by imposing behavioral restrictions on their members. ${ }^{6}$ While such behavioral restrictions impose

\footnotetext{
${ }^{4}$ We regard our setting as being well suited to examine this mechanism, since possible confounding effects from other insurance providers were limited during this period (Appendix Figure 1). Flood insurance was not common at this time (White, 1945), and the few companies that offered such coverage abandoned that business as a result of the 1927 Mississippi flood (Parker, 2000, p.413).

${ }^{5}$ Note, our measure of flood intensity (the fraction of county area flooded) is highly correlated with reported economic damage across counties, thus supporting the assumption that flood intensity is a good exogenous measure of the magnitude of the economic shock that people in the affected areas were exposed to.

${ }^{6}$ One further example is Berman (2000), who argues that the stringent practices and prohibitions imposed
} 
additional costs on potential members, joining stricter denominations should be more attractive after the flood as they can provide a generous mutual insurance network without suffering from free-riding problems. Consequently, these denominations will be better at keeping new members, since free riding is limited. In line with this theoretical prediction, we show that stricter (evangelical/fundamentalist) denominations gained more members in flooded counties.

To further support the hypothesis that social insurance was a central aspect of church membership during the sample period, this study draws on the literature which shows that religious organizations are able to offer members mutual insurance through an extensive church network (Overacker, 1998; Bovee, 2010; Roll, 2010). While spatial diversified risk-sharing arrangements involve a trade-off between risk-pooling benefits and enforcement costs, households can mitigate the enforcement costs by taking part in risk-pooling arrangements with relatives or persons with close ties that are not subject to the same income risk. This can both be along ethnic or religious lines (Rosenzweig and Stark, 1989; Grimard, 1997; Richardson, 2005). Using exclusively the within-county by denomination variation in church membership, we show that the increase in church membership in flooded counties was more pronounced in denominations with a relatively large church network. This finding is consistent with the hypothesis that, after experiencing an adverse economic shock, individuals join denominations with a larger church networks, since these denominations are able to provide access to mutual insurance networks by pooling risk through spatial diversification.

We are able to rule out alternative explanations that could potentially confound the interpretation of our findings. Most importantly, we address the concern that the observed pattern in church membership is driven by flood-induced migration. As flooded counties experienced black out-migration (Hornbeck and Naidu, 2014), a potential confounding factor could be that

on Ultra-Orthodox Jews allow this religious group to sustain a high degree of mutual charity among community members. Iannaccone (1992) argues that religious groups impose observable behavioral restrictions on their members (e.g. requirements on diet, clothing, praying, and social customs), since such restrictions are efficient tools to limit hidden actions (moral hazard). While the associated costs of these restrictive religious practices are considered as unproductive for each individual, they are productive for the religious community, since they increase participation and avoid free-riding. This positive effect on participation is due to screening (avoiding that less committed individuals will become members) and lowering outside options of members; for example, due to stigmatization. In addition, our finding can be understood also as result of signaling, since the theory predicts that lower secular productivity, which arguably was the case for most of the people in the flooded areas, serves as a signal to the local congregations that thee affected people are more likely to contribute to the church in the future since their alternative (secular) use of time has a low value. 
black migrants were less likely to be church members than the average individual. ${ }^{7}$ In that case, total church members per capita in flooded counties could have increased simply due to a composition effect, even if churches in the flooded counties did not gain any new members. However, since there is also a significant increase in total church members in flooded counties we are able to rule this out as the only explanation. Reassuringly, the data and anecdotal evidence also suggest that compositional effects from flood-induced migration are more likely to downward bias our estimated effect. We further show that the effect of the flood on church membership is robust to sample modifications and is not driven by public relief programs such as the New Deal or local redistribution. Overall, our findings support the hypothesis that demand for social insurance is a central determinant of church membership.

\section{Related Literature}

Our paper is most closely related to the literature that emphasizes the role of charity and insurance in religious organizations. ${ }^{8}$ On the theoretical side, economists often regard the insurance function of religious organizations as an important determinant of church membership (Iannaccone, 1992; Berman, 2000; Abramitzky, 2008). In line with these theories, recent empirical research has shown that religious organizations, at least partially, insure their members against economic risk. For example, Deheja, DeLeire, and Luttmer (2007) find that involvement with religious organizations helps individuals to better insure their happiness and consumption against income shocks. ${ }^{9}$

\footnotetext{
${ }^{7}$ In terms of the empirical strategy, our paper also relates to Hornbeck and Naidu, who exploit variation in the impact of the Great Mississippi Flood of 1927 across counties to investigate how the flood affected black out-migration and agricultural development in the American South. We differ from their study by focusing on church membership and by using a larger sample that includes all flooded counties in the seven affected states (the 170 affected counties are located in Louisiana, Mississippi, Arkansas, Tennessee, Missouri, Illinois, and Kentucky).

${ }^{8}$ There is a large literature that investigates the determinants of religious attendance, (e.g., Azzi and Ehrenberg, 1975; Iannaccone 1998; Gruber, 2004, 2005; McCleary and Barro, 2006a; Glaeser and Sacerdote, 2008). One important question in this context is how religious attendance depends on income (e.g., McCleary and Barro, 2006b; Becker and Woessmann, 2013; Franck and Iannaccone, 2014). More generally, a large strand of literature has demonstrated that religion affects economic development in various ways (e.g., Becker and Woessman, 2009; Bénabou, Ticchi, and, Vindigni, 2015; Belloc, Drago, and, Galbiati, 2016; Herzer and Strulik, 2016). See Iyer (2016) for a recent overview of this literature.

${ }^{9} \mathrm{~A}$ separate literature has pointed out that there exists, in general, a positive correlation between religious participation and subjective well-being (e.g., Ellison, 1991; Diener et al., 1999; Luttmer, 2005; Campante and Yanagizawa-Drott, 2015). For example, religion may function as a buffer against adverse life events (e.g.,
} 
Chen (2010) provides evidence that religious institutions can facilitate consumption smoothing by documenting a positive effect of economic distress on religious intensity measured by communal Koran study and Islamic school attendance. ${ }^{10}$ While Chen shows that the effect of economic distress on participation in Islamic religious activities has vanished one year after the period of economic distress, we show an effect on church membership that lasted at least around a decade. Importantly, we show that this long-lasting effect is in line with club good models of religious participation. ${ }^{11}$ In particular, since the rise in church membership after the flood is mainly driven by stricter denominations, our findings are consistent with the prediction of Iannaccone (1992) that stricter denominations are better able to sustain a higher level of mutual insurance among its members because of unproductive costs that limit the attractiveness of other private (secular) activities. Our study also differs from Chen as we study how a large negative economic shock affects religious participation at the aggregate (county) level. ${ }^{12}$

Our work also relates to Ager and Ciccone (2015), who study the link between exposure to economic risk and religious membership based on an ex ante insurance framework. ${ }^{13}$ While Ager and Ciccone show that church membership is higher in societies where people expect more common economic risk, we analyze how the realization of a large economic shock affects church membership by its effect on the demand for social insurance. ${ }^{14}$

A large strand of literature has documented other forms of informal insurance arrangements that are designed to buffer against economic risk when formal insurance markets are absent or incomplete. Besley (1995) provides an introduction to this literature that seeks to Pargament, 1997; Clark and Lelkes, 2005; Scheve and Stasavage, 2006; Bentzen, 2015).

${ }^{10}$ Chen argues that within a religious community people can get help after experiencing a negative economic shock if participation involves high religious intensity associated with a strong group formation and social sanctions on those who leave the community. Thus, ex post insurance is a financially sustainable strategy of communities with strong group formation.

${ }^{11}$ Chen studies the impact of a relative short-run change in the exchange rate and the associated change in consumption, whereas we study an event with huge losses of both income opportunities and assets. The severity of the economic shock might be an additional reason for why we find more long-lasting effects relative to Chen.

${ }^{12}$ Chen reports increased religious participation only of individuals who are affected adversely by relative price shocks induced by the Indonesian financial crisis, whereas individuals who benefited economically from this change decreased their participation. This makes it difficult, based on his findings, to make conclusions about this effect at the aggregate level.

${ }^{13}$ Since the empirical evidence suggests a positive link between religiosity and risk aversion at the individual level (e.g., Miller and Hoffman, 1995; Diaz, 2000; Hilary and Hui, 2009), the link between individual risk aversion and religiosity could influence the decision of religious organizations to provide social insurance.

${ }^{14}$ Specifically, Ager and Ciccone use variability in rainfall as a measure of common economic risk in agricultural counties in nineteenth-century United States and find that religious communities are larger in counties subject to greater rainfall risk. 
explain the causes of informal institutions that provide credit and risk-sharing arrangements and their consequences for economic development. The studies of Alderman and Paxson (1994), Townsend (1995), and Dercon (2004) document that households in developing countries partially share income risk. Such informal risk sharing mechanisms range from implicit insurance provided through family and friend networks (e.g., Rosenzweig and Stark, 1989; Fafchamps and Lund, 2003), fragmentation of land holdings (e.g., McCloskey, 1976), self-enforcing mutualhelp arrangements (e.g., Kimball, 1988; Ligon et al., 2000), informal credits (e.g., Rosenzweig, 1988; Udry, 1994) to spatially diversified mutual-insurance arrangements (e.g., Grimard, 1997; Richardson, 2005). Our analysis complements this literature by providing evidence that religious organizations can be seen as a particular example of a risk-pooling institution that facilitates mutual insurance and credit among their members.

A central building block of our hypothesis is formed by studies showing that religious organizations were the main providers of social services in the United States until the middle of the 20th century (e.g., Gruber and Hungerman, 2007). ${ }^{15}$ For example, during the 1920s, the Presbyterian Church in the United States spent a yearly average of about $\$ 6.50$ per member on benevolences (Weber, 1927, p.141). In 1936, religious organizations spent over $\$ 71$ million on benevolences; alone $\$ 16$ million (about 270 million in 2013 US dollars) on local relief and charity (Bureau of the Census, 1941). More generally, and important for our argument, social insurance in religious organizations involves, in addition to money transfers, a broad range of transactions among members that help individuals to smooth consumption and wellbeing in case of an adverse economic shock (Steinitz, 1982; Taylor and Chatters, 1986, 1988). ${ }^{16}$

Another way of examining whether social services and insurance are important aspects of religious organizations is to test if social services provided by the government crowd out charitable spending of religious organizations. Results from cross-national studies indicate that an increase in government welfare spending is associated with a decline in religious participation, pointing to a substitution effect between church charitable spending and government expen-

\footnotetext{
${ }^{15}$ As churches in the United States required financial support from their members to finance social services, membership was far from costless. Considering only monetary costs, church member giving as a proportion of disposable income ranged between 3 and 3.5 percent in the 1920s (Ronsvalle and Ronsvalle, 1999, Figure 2.1).

${ }^{16}$ Landau (1993) provides an illustrative example, where mutual help among members of Ultra-Orthodox communities comprises not only money and in-kind transfers, but also various time-intensive tasks, such as visiting sick members.
} 
diture for welfare services (e.g., Gill and Lundsgaarde, 2004; Scheve and Stasavage, 2006). ${ }^{17}$ For the United States, Hungerman (2005) finds that a cutback of welfare services to non-US citizens in 1996 increased charitable church spending and member donations of Presbyterian congregations. Gruber and Hungerman (2007) show that local New Deal spending crowded out church charitable activities during the 1930s. As a robustness check, we show that the increase in church membership per capita in flooded relative to non-flooded counties is unaffected by public relief programs such as the New Deal or local public redistribution.

While we argue that demand for social insurance is a main determinant of church membership, the level of religiosity arguably also plays an important role. Thus, an alternative explanation of our findings could be that individuals became more religious after a traumatic experience, such as the Great Mississippi Flood of 1927 (see e.g., Pargament, 1997). For example, Bentzen (2015) shows at a subnational level that religiosity increases after natural disasters. Despite Bentzen documents higher levels of religiosity for second-generation immigrants who's mothers were born in high-earthquake-risk countries, changes in the level of religiosity after a traumatic event seem overall relatively short-lived. Bentzen (2015, Tables A15 and A17), for example, finds that increased religiosity after an earthquake vanishes after less than a decade. Likewise, Belloco, Drago, and Galbiati (2016, page 2) document that the effect of seismic events which retarded the transition of Medieval northern-central Italian cities with bishop seats to communal institutions is confined to the short-run (i.e., the earthquake effect, which Belloco, Drago, and Galbiati consider as shock to people's religiosity and thereby reinforcing the authority of the religious leader, vanishes within 10 years). While not ruling out that religiosity also increased in the immediate aftermath of the flood, the existing evidence that increases in religiosity after natural disasters are relatively short-lived supports our hypothesis. That is, these studies corroborate the hypothesis that the statistically significant and quantitatively substantial increase in church membership in flooded counties, observed almost one decade after the flood, was mainly due to the role churches played as an institution that facilitated mutual

\footnotetext{
${ }^{17}$ Related to this literature is Chen and Lind's (2014) finding that members of religious organizations with greater within-group giving are more opposed to the welfare state and Huber and Stanig (2011), who argue that social services provided by religious organizations based on charitable donations by the rich for lower-income members (so-called religious poor) can affect the political economy of redistribution, as these members form a electoral coalition with the rich in favor of lower taxes and limited redistribution which leaves the secular poor as losers (i.e., non-religious members).
} 
help and support among their members in the years after the flood. ${ }^{18}$

\section{$3 \quad$ Data and Empirical Strategy}

\subsection{Data}

The baseline sample spans a total of 638 counties observed between 1926 and 1936 . These counties constitute the seven affected states: Louisiana, Mississippi, Arkansas, Tennessee, Missouri, Illinois, and Kentucky. ${ }^{19}$ We use data from the Bureau of the Census to construct measures of church membership at the county level. The church membership data were collected in cooperation with local church officials and published in the Census of Religious Bodies. These volumes contain detailed county-level information about church membership of Christian denominations for the years $1890,1906,1916,1926$, and $1936 .{ }^{20}$ County-level church membership, which refers to all religious denominations listed in the Census of Religious Bodies, and population data are retrieved from the ICPSR 2896 file (Haines, 2010).

While the religious censuses of 1890 to 1926 are considered to be detailed and reliable, we are aware of some concerns about the 1936 data (Stark, 1992; Finke and Scheitle, 2005; Gruber and Hungerman, 2007). The Bureau of the Census acknowledged that the 1936 records suffered from undercounting, especially in the South and West, due to lower levels of cooperation compared to previous decades (Gruber and Hungerman, 2007). Several congregations of Southern Baptists and the Methodist Episcopal Church (South), which are both large denominations in the American South, refused to participate and consequently had fewer church members in 1936 compared to 1926 due to underreporting (Finke and Scheitle, 2005). However, to confound our results, the denomination specific underreporting of church members in 1936 needs to be

\footnotetext{
${ }^{18}$ Our findings are also consistent with Bottan and Perez-Truglia (2015), who show that religious values and beliefs during adulthood remained relatively stable even though religious participation decreased dramatically after recent U.S. Catholic clergy abuse scandals.

${ }^{19}$ Our sample is an extension of Hornbeck and Naidu (2014), who consider a restricted sample of 163 counties located in four out of the seven affected states (Louisiana, Mississippi, Arkansas, and Tennessee). As a robustness check, we also use the more restrictive sample (in terms of number of counties) used by Hornbeck and Naidu; see Section 4.3 for details.

${ }^{20}$ Our analysis stops with the official records in 1936. In later studies, such as for the survey of churches and church membership by county in 1952, only a limited number of denominations provided data on religious membership (e.g., only 114 out of 251 religious bodies listed in the Yearbook of American Churches participated in 1952); see www.thearda.com for more details.
} 
systematically related to the Mississippi flood of 1927. Reassuringly, our main findings are not affected if we exclude members of the Southern Baptist Church and the Methodist Episcopal Church (South) - the main denominations associated with underreporting - from our analysis. ${ }^{21}$

The flood intensity captures the share of each county flooded (see Figure 1a). The blue shaded areas indicate the sample region of flooded counties in the seven affected states. Flood intensity is based on the official report of the relief operations of the American Red Cross (1929, Appendix Table VI). Figure 1a shows that counties closer to the Mississippi River were generally more affected by the flood and were more likely to experience an increase in church members per capita between 1926 and 1936 (see Figure 1b). We further collected data from the Mississippi River Flood Control Association (1927) on the economic losses and damages from the Great Mississippi Flood of $1927 .^{22}$ In the supplementary data appendix we provide a detailed description of all variables used in the empirical analysis. Descriptive statistics of the main variables of interest are shown in Table $1 .^{23}$

\subsection{Empirical Strategy}

This section describes the empirical strategy employed to identify the average effect of the Great Mississippi Flood of 1927 on church membership. Since we compare outcomes before and after the flood across counties with different flood intensities (measured as the fraction of county area flooded in 1927), our empirical framework follows a differences-in-differences (DD) strategy.

The baseline estimation equation is:

$$
M_{c t}=\delta_{c}+\varphi_{s t}+\beta \text { Flood }_{c} \times I_{t}^{\text {post }}+\mathbf{X}_{c} \mathbf{I}_{t}^{\text {post }} \Gamma+\varepsilon_{c t}
$$

where $M_{c t}$ denotes the measure for church membership (church members per capita or the logarithm of total church members) in county $c$ at time $t$; Flood is $_{c}$ the fraction of county

\footnotetext{
${ }^{21}$ We present these results in Section 4.3.

${ }^{22}$ We prefer the share of each county flooded as the main measure of flood intensity rather than using the resulting economic losses and damages from the flood, since the former measure is based on geographic characteristics and not on counties' pre-flood economic activity.

${ }^{23}$ The measure of total church members relative to population is above unity in Jefferson Parish (LA) (1.04) and in Vermilion Parish (LA) (1.11). Our results are unaffected if these counties (parishes) are excluded from the analysis or if we truncate this variable at unity; see Section 4.3 for more details.
} 
area flooded; and $I_{t}^{\text {post }}$ is an indicator variable that equals one in the post-treatment period (i.e., $t=1936$ ) and zero in the pre-treatment period (i.e., $t=1926$ ). We also control nonparametrically for county fixed effects $\left(\delta_{c}\right)$ to capture time-invariant factors that affect both church membership and the fraction of county area flooded, such as geography, and state-bytime fixed effects $\left(\varphi_{s t}\right)$ to capture any time-varying factors at the state level, such as statewide policy changes. $\mathbf{X}_{c} \mathbf{I}_{t}^{\text {post }}$ denotes a set of county-specific geographical characteristics (i.e., latitude, longitude, cotton and corn suitability, ruggedness, and distance to the Mississippi River) interacted with the time indicator. We compute standard errors that are Huber robust and clustered at the county level. ${ }^{24}$ In addition, we report standard errors of the point estimates that are corrected for spatial correlation (Conley, 1999). Following Hornbeck and Naidu (2014), the regressions are weighted by county size.

\section{Results}

\subsection{Flexible Results}

Before reporting the results from estimation equation (1), we test the key identifying assumption in the DD strategy of common pre-trends between treatment and control counties using the following flexible model:

$$
M_{c t}=\delta_{c}+\varphi_{s t}+\sum_{j=1906}^{1936} \beta_{j} \text { Flood }_{c} \times I_{t}^{j}+\sum_{j=1906}^{1936} \mathbf{X}_{c} I_{t}^{j} \Gamma_{j}+\varepsilon_{c t}
$$

where the main difference to estimating equation (1) is that Flood $_{c}$ and $\mathbf{X}_{c}$ are interacted with a full set of year fixed effects, $\sum_{j=1906}^{1936} I_{t}^{j}$. The sample length is now extended to 1890-1936. Since 1890 is the (omitted) year of comparison, the estimated $\beta_{j}^{\prime} s$ denote the effect of being flooded in 1927 on the outcomes $\left(M_{c t}\right)$ for every year we consider relative to 1890 . A test of the DD-identifying assumption is that the coefficients in the pre-treatment periods are zero, implying that there should only be an effect of the flood in the post-treatment period in 1936 (i.e., $\hat{\beta}_{1906} \approx \hat{\beta}_{1916} \approx \hat{\beta}_{1926} \approx 0$ and $\left.\hat{\beta}_{1936} \neq 0\right) .{ }^{25}$

\footnotetext{
${ }^{24}$ This type of clustering allows the residuals to be arbitrarily serially correlated within counties.

${ }^{25}$ See, for example, Angrist and Pischke (2008).
} 
Table 2 presents the results from the estimating equation (2). We show estimates for church members per capita in columns (1)-(3) and estimates for the logarithm of total church members in columns (4)-(6). While there are positive differences in the pre-treatment periods in columns (1) and (4), where we only control for county and year fixed effects, these effects disappear once we add state-by-time fixed effects in column (2). Importantly, the positive and statistically significant effect for the post-treatment period remains. Thus, consistent with the hypothesis that the flood in 1927 caused an increase in church membership, more flooded counties experienced an increase in church members per capita relative to non-flooded counties only after 1927 when the flood took place.

Column (3) reports estimates from a specification that controls for the set of geographic variables (latitude, longitude, cotton and corn suitability, ruggedness, and distance to the Mississippi River) interacted by the set of year fixed effects. As seen from Figure 2, which visualizes the estimates from this specification, there are no significant differences in pre-trends between treatment and control counties related to the future flood share. We reach the same conclusion when we use the logarithm of total church members as outcome variable in columns (4)-(6). Thus, the key assumption in the DD framework, i.e., that treatment and control counties follow common pre-trends, is not violated. Since we also find a positive and statistically significant effect on total church members, the effect on church members per capita cannot only be driven by non-members moving out of the flooded counties. ${ }^{26}$ We also note that the results in Table 2 are robust to the functional form and controlling for county-specific linear time trends. ${ }^{27}$

Overall, the results from the flexible specification show that there are no significant pretrends once we account for state-by-time fixed effects. When we add these controls, a clear positive effect of flooding on church membership (in total and relative to population) emerges after the 1927 flood. Changing the comparison year to, for example, 1926 provides a similar picture; that is, $\hat{\beta}_{1890} \approx \hat{\beta}_{1906} \approx \hat{\beta}_{1916} \approx 0$ and $\hat{\beta}_{1936}>0$. Thus, there is a clear and distinct discontinuity in the pattern of the church membership after the 1927 flood and no signs in the data that the key identifying assumption of our empirical strategy is violated.

\footnotetext{
${ }^{26}$ We refer to Section 4.3.1 for a detailed discussion of the potential effects from flood-induced migration.

${ }^{27}$ These results are available from the authors upon request.
} 


\subsection{Main DD Results}

In this section, we discuss the estimates from the DD specification of equation (1) using 1926 as the pre-treatment period and 1936 as the post-treatment period. Table 3 reports the DD estimates. Column (1) shows a positive and statistically significant association between flooded counties and church members per capita controlling for county and year fixed effects. The point estimate implies that a fully flooded county experienced a 15.9 percentage point increase in church membership per capita relative to a non-flooded county.

One concern is that the flood correlates with unobserved state-specific changes in church membership per capita during the considered period. It is also plausible that geographical characteristics that are correlated with the flood have changed over time and directly influence church membership. As seen from columns (2) and (3), our main result is robust to controlling for state-by-time fixed effects and the set of geographical variables interacted with time. Reassuringly, the point estimate, $\hat{\beta}=0.16$ (standard error $=0.037$ ), is strikingly similar to the estimate reported in column (1).

Figure 3 plots the partial relationship between Flood $_{c} \times I_{t}^{\text {post }}$ and church members per capita from column (3). This scatter plot allows for visual inspection of our baseline specification. It could be argued that the four observations located in the Northeast and Southwest corners of the plot are outliers. If these are excluded we find that $\hat{\beta}=0.11$ (standard error $=0.032$ ), which shows that the effect is not a result of these outliers. Moreover, Appendix Table 1 demonstrates that the baseline results are also robust to excluding counties with outcomes in the 1st, 5th, 95th, and 99th percentiles.

Columns (4)-(6) document the effects of the flood on total church members. In column (6) we find a positive and statistically significant association between the flood and total church membership at the 1-percent level. The point estimate implies that flooded counties experienced a 32 percent relative increase in total church members. ${ }^{28}$ Note that we obtain similar results for both outcome variables in Table 3, as flooded and non-flooded counties follow the same pattern in population growth after the shock (see Figure 4). ${ }^{29}$

\footnotetext{
${ }^{28}$ Results of Table 3 remain quantitatively and qualitatively unchanged when controlling for initial (1926) church membership per capita (or total church members in 1926) interacted with time (available from the authors upon request).

${ }^{29}$ The estimated coefficient on the fraction of county land flooded is also statistically significant at the 1-
} 


\subsection{Robustness}

We have carried out a number of robustness checks on the baseline estimating equation. Appendix Table 2 shows that the results are qualitatively similar if we restrict the control counties to be no further than $50 \mathrm{~km} / 75 \mathrm{~km} / 100 \mathrm{~km}$ away from the Mississippi river (columns 1-3), bordering the flooded region (column 4), or using the restricted sample of Hornbeck and Naidu (2014) of 163 counties (column 5). ${ }^{30}$ Appendix Table 3 demonstrates that the findings in Table 3 are also robust to excluding the main Southern denominations subject to underreporting of members (Southern Baptist Church and the Methodist Episcopal Church, South). We also use a falsification exercise, where we assume that the flood took place either between 1890 and 1900, 1900 and 1910, or 1910 and 1920 to check the validity of our results. Appendix Table 4 reports that flooded counties changed similarly to non-flooded counties in those years supporting the identifying assumption that in the absence of the 1927 Mississippi flood, treatment and control counties would have changed similarly over time. In the following subsections, we show that our findings are not driven by flood-induced migration and public relief programs such as the New Deal and local public redistribution.

\subsubsection{Flood-induced Migration}

A potential threat to the identification is the possibility that the Great Mississippi Flood of 1927 triggered migration of individuals, who differed from stayers in terms of church membership. Since Hornbeck and Naidu (2014) document black out-migration from flooded counties, a threat would be if black migrants were not representative in terms of church membership. Our baseline estimate would be upward biased if, compared to the average individual in flooded counties, black migrants were less likely church members. First, we note that anecdotal evidence indicates that this is unlikely to be the case. For example, Sernett (1997) and Overacker (1998) report that black migration to the North was, to a large extent, facilitated by church networks, which is consistent with the above-mentioned theories highlighting the insurance aspect in form of

percent level when using unweighted least squares regressions.

${ }^{30}$ Note that the sample selection criteria in Appendix Table 2 is based on geographic proximity to the Mississippi river (columns 1-3) or closeness to the flooded counties (column 4), while Hornbeck and Naidu' sample includes only contiguous counties in Arkansas, Louisiana, Mississippi, and Tennessee if the 1920 black share exceeds 0.1 and the fraction of cropland planted in cotton in 1920 is above 0.15 . 
mutual help and support among church members. Thus, if anything, our estimate is likely to be downward-biased, as black migrants leaving the American South were more likely to be church members than the average person staying in the flooded areas. ${ }^{31}$

In addition, we can reject the hypothesis that out-migration of non-members was the only reason why church members per capita increased in flooded counties, since we also documented a corresponding increase in total church members in Section 4.2. The similar evolution of populations in flooded and non-flooded counties during the period of interest (see Figure 4) reveals why we find similar effects when we use total church members instead of church members per capita as dependent variable. Based on these arguments, and the available anecdotal evidence, we conclude that flood-induced out-migration is unlikely to explain our findings.

The evolution of population size shown in Figure 4 is consistent with Hornbeck and Naidu (2014, Table 2, columns 5-6), who find no statistically significant differences in total population size between flooded and non-flooded counties. Column (1) of Table 4 confirms this finding, where in equation (1) we replaced church membership by total population size as the dependent variable. Our results indicate that the decline in black population was offset by an increase in white (and other non-black) population in flooded counties. Thus, the increase in total church membership in flooded counties might be a result of white in-migration if these migrants were more likely to be church members compared to the average population in the flooded counties.

In this case, it is important to distinguish between two scenarios. The first scenario is that people, who moved from non-flooded counties into flooded counties were mainly church members. For this explanation to hold, we would expect to see a negative effect on the evolution of church members in non-flooded counties compared to the rest of the American South. As Figure 5 shows, this was not the case. On the contrary, the evolution in church membership in non-flooded countries is remarkably similar to that of the rest of the South. We conclude that people who moved between flooded and non-flooded counties did not seem to have been special in terms of church membership. The second scenario is that churches facilitated that members from the entire United States moved into the flooded counties due to the need for

\footnotetext{
${ }^{31}$ For example, Sernett (1997, pp.76-77) writes: "In some instances ministers arrived in the North with enough members of their old congregations to immediately organize a church. The Rev. R.H. Harmon brought twentyeight members of his congregation from Mississippi to Chicago. He told a Defender reporter: I am working at my trade. I have saved enough to bring my wife and four children and some of my congregation. We are here for keeps".
} 
people to help with the provision of relief and reconstruction. In that case we would also expect to see a corresponding increase in the number of clergymen per capita. As Table 4, column (2) shows, this was also not the case. ${ }^{32}$ We should note that even if our results are partly a result of in-migration of white church members this can still be viewed as broadly consistent with the "insurance hypothesis" of church membership. For example, Roll (2010, p.6) writes: "Religious fellowship enabled migrant settler families in the [Missouri] Bootheel to form new communities and organize politically. Churches, which often were the only meeting places available to rural people, became important civic spaces where a shared moral system that ordered ideas about families, labor, leadership, and belonging could be enunciated and enforced." A placebo test where we assume that non-flooded counties no further than 50 (100) $\mathrm{km}$ away from the Mississippi river are treated and non-flooded counties that are at least 50 to100 (100 to 200) km away from the Mississippi river are considered as control counties reveals no significant effect on church membership, which indicates that in-migration to flooded counties should be less of a concern in case most of the population inflow to the flooded areas came from nearby non-flooded counties. ${ }^{33}$

Columns (3)-(8) of Table 4 present further robustness checks. In columns (3)-(5) the outcome variable is church members per capita. In column (3), we add county population size over the decade 1920-1930 as additional control variable to the benchmark specification (i.e., column (3) of Table 3). As expected, the estimated coefficient on the fraction of county land flooded remains quantitatively and qualitatively unaffected. Our main result also remains unchanged when we control for black population over the decade 1920-1930 in column (4). Column (5) includes the initial (1920) share of the county population who were black interacted with the time indicator as additional control. This should capture any differential effect, including induced migration, between blacks and whites from the flood. The estimated coefficient on the fraction of county land flooded remains positive and statistically significant at the 1-percent level, although the coefficient in column (5) becomes somewhat smaller. ${ }^{34}$ Column (6) documents that

\footnotetext{
${ }^{32}$ If the decision to migrate is affected by transportation costs, and these are increasing with the distance to the flooded areas, we would expect to see more church members coming from counties close to the flooded region (i.e., the non-flooded counties in our sample). Again, since these counties have a similar trend in the evolution of church members as the rest of the American South (see Figure 5), the data do not support this explanation.

${ }^{33}$ The estimated coefficient is $-0.002 / 0.034$ with a standard error $(0.034 / 0.022)$ for treated placebo counties that were at least $50 / 100 \mathrm{~km}$ away from the Mississippi river (available from the authors upon request).

${ }^{34}$ Our main result remains unaffected if we include the share of blacks over the decade 1920-1930 as additional
} 
our finding for total church members is robust to controlling for initial (1920) black population interacted with the time indicator. In the two final columns, we only exploit variation in church members relative to population within purely white and black denominations. ${ }^{35}$ Importantly, the flood had a positive and statistically significant effect in both specifications suggesting that our main result is not driven by race-specific denominations.

Appendix Table 5 further shows that the positive effect of the Great Mississippi Flood of 1927 is not driven by differences in national cultures. The US Census collected county-level data of the population by birthplace in 1920. When including the interaction of the 1920 nationality shares with time, the coefficient of interest remains unaffected and statistically significant at the 1-percent level. Overall, the presented evidence does not support the hypothesis that floodinduced migration or other changes in the composition of the population were the main causes of the increase in church membership.

\subsubsection{Redistribution and Public Relief}

In Table 5, column (1) we add per capita tax revenues at the county level as a further control variable to our benchmark specification. This variable serves as a proxy for local redistribution (Ramcharan, 2010). Reassuringly, our coefficient of interest remains unaffected and statistically significant at the 1 percent level.

Since we compare church membership between 1926 and 1936, our period includes the New Deal and the associated expansion of government spending during the 1930s. This is a potential threat to the identification of the hypothesized insurance mechanism, since Fishback et al. (2005) argue that counties with major rivers received more relief through the New Deal. Moreover, Gruber and Hungerman (2007) find that the New Deal crowded out church charitable spending of six large Christian denominations in the 1930s. To address this concern, we include in columns (2)-(5) of Table 5 controls for the New Deal program interacted with the time indicator. ${ }^{36}$ We find that the effect of the flood on church members per capita remains positive control (available from the authors upon request).

${ }^{35}$ We use information from the Census of Religious Bodies to classify denominations along racial lines. While most of the so-called "black churches" were listed separately, some denominations grouped black and white members in the Census together. While these "mixed denominations" are not included in columns (7)-(8), using church members of mixed denominations relative to population as dependent variable yields qualitatively similar results (available from the authors upon request).

${ }^{36}$ This is equivalent to controlling for the change in New Deal spending as there were all zero in the pre- 
and statistically significant at the 1 percent level. Thus, within the considered time span, the effect of the flood on church membership was not mitigated by the New Deal spending program. $^{37}$ Overall, the evidence presented in Table 5 shows that our results are robust to public relief spending (i.e., the New Deal) and local redistribution of income through county taxes.

\section{Mechanisms}

Before presenting detailed evidence on the insurance hypothesis, we provide a brief discussion of the different competing mechanisms that could have triggered individuals' demand for social insurance after the 1927 flood.

On the theoretical side, the effect of the flood on individuals' risk perception is distinct from the direct impact that an adverse economic shock has on income and wealth of the affected people. Since the Great Mississippi Flood of 1927 was an unprecedented disaster, it is hard to argue that individuals in the affected areas did not update their risk perception in the period after 1927. This notion is further supported in Daniel (1997, p.3) reporting that the Chief of Engineers concluded that the levees in 1926 were in a condition to prevent the destructive effect of floods. Even if individuals' risk perception would remain unchanged, the flood might have affected church membership by its devastating impact on the local economy. ${ }^{38}$ People who lost their homes and property could seek help and relief from religious organizations resulting in an increased demand for ex post insurance (Chen, 2010). Indeed, clergymen of any denomination asked their congregations for flood fund contributions to help affected people in the Red Cross refugee camps (American National Red Cross, 1929, pp.16-17). Even though urgent relief was probably not contingent on joining a church, the situation in the affected areas made a connection between relief and church membership likely, ${ }^{39}$ in particular since denominations did

treatment period.

${ }^{37}$ Our finding does not rule out that the New Deal spending crowded out charity spendings of churches and thus ultimately lowered church membership in the long run.

${ }^{38}$ For example, one could argue that the risk of future floods is similar in flooded and nearby non-flooded counties, given the locations where the levees broke are considered as random.

${ }^{39}$ There is some evidence, however, that churches tend to provide social services mainly to their own members, and those who demand the services are overwhelmingly religious (Wuthnow, 2004; Livezey, 2000; McRoberts, 2003). 
not forgo the opportunity to attract new members in the refugee camps. As reported in Daniel (1977, p.168), "Evangelical preachers, like home demonstration agents, treated the massive relief camps as missionary fields ripe unto the harvest".

Based on the above-mentioned anecdotal evidence, we believe that the demand for local relief and charity and the change in individuals' risk perception in the affected areas both contributed to the increased demand for social insurance, and thereby church membership, in flooded areas. We therefore think of our hypothesis as encompassing both explanations. ${ }^{40}$

\subsection{Economic damage, credit and fundamentalism}

Table 6 strongly suggests that the impact of the flood on church membership had an economic foundation. In columns (1) and (2), we use the property damage data from the Mississippi River Flood Control Association to show the direct effect of economic damage on church membership. For both specifications, the estimated coefficient on economic damage is positive and statistically significant at the 1-percent level. The point estimate in column (2) implies that a 1percent increase in economic damage implies an increase in church membership of 2.35 percent. Column (3) documents that the intensity of the flood is highly correlated with actual economic damage indicating that the increase in church membership is driven by economic losses due to the Great Mississippi Flood of 1927.

Table 7 provides further support of the insurance hypothesis. Column (1) shows that credit availability (measured by the number of banks per 1,000 inhabitants in 1926) mitigates the effect of the shock on church membership. In particular, the estimated coefficient on the interaction term indicates that a one-standard deviation increase in banks per 1,000 inhabitants in 1926 reduces the magnitude of the shock by about 15 percentage points. The results remain qualitatively unchanged if we add the 1920 urbanization share interacted with time as further control. Column (3) of Table 7 also reports a negative effect when using the value of bank deposits per 1,000 inhabitants in 1926, although the estimated coefficient on the interaction term is not statistically significant at conventional levels. In column (4) the point estimate of the interaction term increases, however, in absolute magnitude and becomes statistically

\footnotetext{
${ }^{40}$ While it would be interesting to disentangle the flood's direct effect from changes in risk perception, the lack of systematic individual data makes this impossible to implement.
} 
significant at the 1-percent level once we include 1920 urbanization share interacted with time. Consistent with the insurance hypothesis, our findings suggest that access to credit mitigates the needs of individuals to join religious communities in times of economic distress.

In Table 8, we test a key prediction of the club good theory (Iannaccone, 1992): stricter denominations are better capable of providing social insurance among its members. Since the Census of Religious Bodies in the United States collected data on church membership by county and denomination we can divide the denominations in our sample into two categories; fundamental and liberal by following the classification of Steensland et al. (2000). As shown in Iannaccone (1992), these denominations can also be classified as strict, as there is a close connection between the degree of strictness and the degree of fundamentalism across denominations. Consistent with the theoretical prediction, column (1) shows that membership in fundamental denominations significantly increased after the flood in per capita terms, while column (2) documents that fundamental denominations also gained relative to other denominations in the affected counties. Overall, the estimates of Table 8 reveal that stricter denominations largely account for the substantial increase in church membership after the Great Mississippi Flood of 1927.

\subsection{Denomination-specific Evidence}

As the Census of Religious Bodies provides membership data by county and denomination, we can exploit the variation in flood intensity across counties and time together with variation in denomination specific characteristics to further study the insurance mechanism through which the flood increased church membership.

We consider the following estimating equation:

$$
M_{d c t}=\varphi_{d t}+\gamma_{c t}+\gamma \text { Flood }_{c} \times I_{t}^{\text {post }} \times \text { Index }_{d}+\epsilon_{d c t}
$$

where $M_{d c t}$ denotes members of denomination $d$ per capita in county $c$ at time $t$. The flood-shock variable, Flood $_{c} \times I_{t}^{\text {post }}$, is now interacted with a denomination-specific index, Index $d$, which is explained as the analysis progresses. Our specification also controls non-parametrically for 
county-by-time fixed effects $\left(\gamma_{c t}\right)$ and denomination-by-time fixed effects $\left(\varphi_{d t}\right) .{ }^{41}$ Regressions are weighted by county size and standard errors are clustered at the county level.

We construct indices based on denominations' charity-orientation, network size and fundamentalism (strictness) to capture the predictions from the above-mentioned theories regarding the ability of religious organizations to facilitate social insurance among members. ${ }^{42}$ One aspect of determining whether the insurance motive plays a major role in religious organizations is to evaluate how much weight denominations put on charity and local relief. We construct a charity index using information on local relief and charity expenditures from the Census of Religious Bodies in $1936 .^{43}$ The charity index ranks denominations according to how much they spent on charity and local relief relative to other expenditures (extensive margin). A higher score indicates that a given denomination is considered to be more charity-oriented.

The capability of a denomination to offer spatially diversified risk-sharing arrangements is of importance when members require an insurance scheme against common local agricultural risk, such as floods or crop failures. The scope of the disaster in 1927 may have limited the insurance capacity within congregations in flooded counties thus making membership more attractive in denominations that could draw on a large church network outside the affected areas. ${ }^{44}$ We construct a network index, which captures the overall size of church networks using information from the Census of Religious Bodies in 1926, ranking denominations according to the total number of churches. A higher score indicates that a given denomination has the possibility to

\footnotetext{
${ }^{41}$ Note that the county-by-time fixed effects absorb the direct effect of the flood-shock variable, Flood $_{c} \times I_{t}^{\text {post }}$. The direct effects of the denomination specific index, Index $d$, is absorbed by the denomination-by-time fixed effects.

${ }^{42}$ In our sample, congregations had on average about 80 members per church in 1890 . Since the average congregation size in our sample is relatively small, social sanctions should still work effectively and mitigate the moral hazard problem. See, for example, Abramitzky (2008) for a related discussion on group size and moral hazard for the Israeli kibbutzim.

${ }^{43}$ We use data from the 1936 Census on expenditures for local relief and charity separately by denomination, since these variables are not reported in the 1926 Census. Although the flood possibly had a direct effect on the level of expenditures on local relief and charity, it may also have had an affect other expenditures, e.g. improvements (reconstruction) of churches. Accordingly, we use the expenditures on charity and relief as a share of total expenditures. While some churches in the affected area probably increased their expenditure share spend on charity and relief in response to the flood, we make the index based on the assumption that this local effect was not large enough to change the rankings of denominations, at the national level, in terms of share of total expenditures spent on charity and local relief between 1926 and 1936.

${ }^{44}$ However, it is important to mention that it was still possible to sustain support networks within flooded counties as not all residents were flood victims (only 24 out of 638 counties experienced more than 50 percent of their land being flooded).
} 
draw on a larger church network.

To evaluate whether stricter denominations gained more members in flooded counties we construct an index of religious strictness (fundamentalist index) following the classification scheme used for Table 8. Denominations classified as liberal are assigned a zero, whereas denominations classified as fundamentalist obtain a one, such that stricter (fundamentalist) denominations obtain a score.

Table 9 reports the results from using these three indices each interacted with the flood variable. The estimating equation is (3) and the estimation method is least squares weighted by county size. The effect between the interaction terms and church membership is positive and highly statistically significant. Consistent with club good models that link church membership to social insurance, we find that denominations in flooded counties gained more members if they (i) spent a larger share of expenditure on charity-related activities, (ii) had access to a larger church network, (iii) had more fundamental religious values.

\section{Concluding remarks}

Club good models propose that economic incentives affect religious participation and stress mutual insurance in religious communities as a central reason for their existence. However, empirical studies supporting the main prediction of these models are still relatively scarce. This paper aims to fill this gap by analyzing how a change in the demand for social insurance triggered by a large negative economic shock affected church membership. In this respect, the Great Mississippi Flood of 1927 provides an excellent opportunity to test the insurance hypothesis of church membership, as alternative means of insurance in the flooded affected areas were largely absent at that time (Appendix Figure 1).

The presented empirical evidence documents a strong positive effect of the Great Mississippi Flood of 1927 on church membership. Economic incentives turned out to be the key driver for the surge in church membership in the affected areas. Our results indicate that the flood-induced increase in church membership was largely driven by economic losses and damages that people had to bear after that catastrophic event. In the flooded areas, stricter denominations gained in relative importance and incresed the overall membership rate, which is consistent with the 
idea that stricter denominations are better able to sustain a higher level of mutual insurance among its members. While joining stricter denominations might be beneficial for individuals in the short run, community ties restrict members' mobility and economic opportunities in the long run. In that sense, the behavioral restrictions and sacrifices imposed by stricter religious communities to prevent free riding and limiting the attractiveness for their members to pursue other secular activities can impose a barrier to economic growth. Whether the rise of stricter denominations after the flood was permanent and potentially hampered economic growth in the affected areas goes beyond the scope of the current paper.

Overall, our findings suggest that the positive effect on church membership was a result of increased demand for social insurance during a period of economic hardship. While mainly stricter denominations accounted for the rise in church membership in flooded counties, we also find that credit availability mitigated the effect of the flood on church membership, thereby supporting the insurance hypothesis proposed by club good theory (Iannaccone, 1992; Berman, 2000; Abramitzky, 2008). Future research may try to bridge the literature on religion and non-market credit institutions further to increase the understanding of the role that religion plays in the process of economic development. 


\section{References}

Abramitzky, R. (2008), "The Limits of Equality: Insights from the Israeli kibbutz", The Quarterly Journal of Economics, 123, 1111-1159.

Ager, P. and Ciccone, A. (2015), "Agricultural Risk and the Spread of Religious Communities", EHES Working Papers in Economic History, No.74.

Alderman, H. and Paxson, C. H. (1994), "Do the Poor Insure? A Synthesis of the Literature on Risk and Consumption in Developing Countries", in Bacha, E.L. (ed.), Economics in a Changing World, Vol. 4, Development, Trade, and Environment (MacMillan, UK).

American National Red Cross (1929), The Mississippi Valley Flood Disaster of 1927; Official Report of the Relief Operations (Washington, D.C.: The American National Red Cross).

Angrist, J. D., and Pischke, J. S. (2008). Mostly Harmless Econometrics: An Empiricist's Companion (Princeton University Press).

Azzi, C. and Ehrenberg, R. G. (1975), "Household Allocation of Time and Church Attendance", The Journal of Political Economy, 83, 27-56.

Becker, S. O. and Woessmann, L. (2009), "Was Weber Wrong? A Human Capital Theory of Protestant Economic History", Quarterly Journal of Economics, 124, 531-596.

Becker, S. O. and Woessmann, L. (2013), "Not the Opium of the People: Income and Secularization in a Panel of Prussian Counties", American Economic Review, Papers and Proceedings, 103, 539-544.

Belloc, M., Drago, F., and Galbiati, R. (2016), "Earthquakes, Religion, and Transition to Self-Government in Italien Cities", Quarterly Journal of Economics, forthcoming.

Bénabou, R., Ticchi, D., and Vindigni, A. (2015). "Religion and Innovation". The American Economic Review, Papers and Proceedings, 105, 346-351.

Bentzen, J. (2015), "Acts of God: Religiosity and Natural Disasters Across Subnational World Districts" Working paper. 
Berman, E. (2000), "Sect, Subsidy and Sacrifice: an Economist's View of Ultra-Orthodox Jews", Quarterly Journal of Economics, 115, 905-953.

Besley, T. (1995). "Nonmarket Institutions for Credit and Risk Sharing in Low-Income Countries", The Journal of Economic Perspectives, 9, 115-127.

Bottan, N. L., and Perez-Truglia, R. (2015). Losing my religion: The effects of religious scandals on religious participation and charitable giving. Journal of Public Economics, 129, 106-119.

Bovee, D. S. (2010). The Church and the Land: The National Catholic Rural Life Conference and American Society, 1923-2007 (The Catholic University of America Press, USA).

Bureau of the Census (1930), Religious Bodies: 1926, Volume I, Summary and Detailed Tables (Washington D.C., United States Government Printing Office).

Bureau of the Census (1941), Religious Bodies: 1936, Volume I, Summary and Detailed Tables (Washington D.C., United States Government Printing Office).

Campante, F. and Yanagizawa-Drott, D. (2015), "Does Religion affect Economic Growth and Happiness? Evidence from Ramadan", Quarterly Journal of Economics, 130, 615-658.

Chen, D. L. (2010), "Club Goods and Group Identity: Evidence from Islamic Resurgence during the Indonesian Financial Crisis", Journal of Political Economy, 118, 300-354.

Chen D. L. and Lind, J. (2014), "The Political Economy of Beliefs: Why Fiscal and Social Conservatives/Liberals Come Hand-in-Hand" (Mimeo, ETH Zurich).

Clark, A. and Lelkes, O. (2005), "Deliver us from Evil: Religion as Insurance" (Mimeo, ParisJourdan Sciences Economiques).

Cnaan, R. A. and Boddie, S. C. (2002), The Invisible Caring Hand: American Congregations and the Provision of Welfare (New York: New York University Press).

Conley, T. G. (1999), "GMM Estimation with Cross Sectional Dependence", Journal of Econometrics, 92, 1-45. 
Cornes, R. and Sandler, T. (1986). The Theory of Externalities, Public Goods and Club Goods (New York: Cambridge University Press, 1986).

Daniel, P. (1977), Deep'n as it Come: The 1927 Mississippi River Flood (New York: Oxford University Press).

Dehejia, R., DeLeire, T. and Luttmer, E. F. P. (2007), "Insuring Consumption and Happiness through Religious Organizations", Journal of Public Economics, 91, 259-279.

Dercon, S. (2004), "Risk, Insurance, and Poverty: A Review", in Dercon, S. (ed.), Insurance Against Poverty (Oxford University Press, UK).

Diaz, J. D. (2000), "Religion and Gambling in Sin-City: A Statistical Analysis of the Relationship Between Religion and Gambling Patterns in Las Vegas residents", Social Science Journal, 37, 453-458.

Diener, E., Suh, E. M., Lucas, R. E. and Smith, H. L. (1999), "Subjective Well-Being: Three Decades of Progress", Psychological Bulletin, 125, 276-303.

Ellison, C. G. (1991), "Religious Involvement and Subjective Well-Being", Journal of Health and Social Behavior, 32, 80-99.

Fafchamps, M. and Lund, S. (2003), "Risk-Sharing Networks in Rural Philippines", Journal of Development Economics, 71, 261-287.

FAO (2012), Global Agro-Ecological Zones (GAEZ v3.0). IIASA, Laxenburg, Austria and FAO, Rome.

Farr, T. G., et al. (2007), "The Shuttle Radar Topography Mission", Reviews of Geophysics, 45, RG2004.

Federal Deposit Insurance Corporation (2001). Federal Deposit Insurance Corporation Data on Banks in the United States, 1920-1936. [Computer file]. ICPSR ed. Ann Arbor, MI: Interuniversity Consortium for Political and Social Research [producer and distributor], 2001.

Finke, R. and Scheitle, C. P. (2005), "Accounting for the Uncounted: Computing Correctives for the 2000 RCMS Data", Review of Religious Research, 47, 5-22. 
Fishback P. V., Horrace, W. and Kantor, S. (2005), "The Impact of New Deal Expenditures on Local Economic Activity: An Examination of Retail Sales, 1929-1939", Journal of Economic History, 65, 36-71.

Fishback, P. V., Troesken W., Kollmann T., Haines, M., Rhode, P. W. and Thomasson, M. (2011), "Information and the Impact of Climate and Weather on Mortality Rates during the Great Depression", in The Economics of Climate Change: Adaptations Past and Present, University of Chicago Press, 131-167.

Franck, R. and Iannaccone, L. R. (2014), "Religious Decline in the 20th Century West: Testing Alternative Explanations?", Public Choice, 159, 385-414.

Gill, A. and Lundsgaarde, E. (2004), "State Welfare Spending and Religiosity A Cross-National Analysis", Rationality and Society, 16, 399-436.

Glaeser, E. L. and Sacerdote, B. I. (2008), "Education and Religion", Journal of Human Capital, 2, 188-215.

Grimard, F. (1997), "Household Consumption Smoothing through Ethnic Ties: Evidence from Cote d'Ivoire", Journal of Development Economics, 53, 391-422.

Gruber, J. H. (2004), "Pay or pray? The Impact of Charitable Subsidies on Religious Attendance", Journal of Public Economics, 88, 2635-2655.

Gruber, J. H. (2005), "Religious Market Structure, Religious Participation and Outcomes: Is Religion Good for You?", The B.E. Journal of Economic Analysis 69 Policy, 5, Article 5.

Gruber, J. H. and Hungerman, D. M. (2007), "Faith-Based Charity and Crowd-out during the Great Depression", Journal of Public Economics, 91, 1043-1069.

Haines, M. R. and Inter-university Consortium for Political and Social Research (2010), Historical, Demographic, Economic, and Social Data: The United States, 1790-2002. ICPSR02896v3. Ann Arbor, MI: Inter-university Consortium for Political and Social Research [distributor], 2010-05-21. http://doi.org/10.3886/ICPSR02896.v3 
Herzer, D., and Strulik, H. (2016). "Religiosity and Long-Run Productivity Growth". Cege Discussion Papers Number 284.

Hilary, G. and Hui, K. W. (2009), "Does Religion Matter in Corporate Decision Making in America?", Journal of Financial Economics, 93, 455-473.

Hornbeck, R. and Naidu, S. (2014), "When the Levee Breaks: Black Migration and Economic Development in the American South", American Economic Review, 104, 963-990.

Huber, J. D. and Stanig, P. (2011). "Church-state separation and redistribution", Journal of Public Economics, 95, 828-836.

Hungerman, D. M. (2005), "Are Church and State Substitutes? Evidence from the 1996 Welfare Reform", Journal of Public Economics, 89, 2245-2267.

Iannaccone, L. R. (1992), "Sacrifice and stigma: reducing free-riding in cults, communes, and other collectives", The Journal of Political Economy, 100, 271-291.

Iannaccone, L. R. (1994), "Why Strict Churches Are Strong", American Journal of Sociology, 99, 1180-1211.

Iannaccone, L. R. (1998), "Introduction to the Economics of Religion", Journal of Economic Literature, 36, 1465-1495.

Iyer, S. (2016). The New Economics of Religion. Journal of Economic Literature, 54, 395-441.

Kimball, M. S. (1988), "Farmers' Cooperatives as Behavior toward Risk", American Economic Review, 78, 224-232.

Landau, D. (1993). Piety and Power: The World of Jewish Fundamentalism. New York: Hill and Wang.

Ligon, E., Thomas, J. P. and Worrall, J. (2000), "Mutual Insurance, Individual Savings, and Limited Commitment", Review of Economic Dynamics, 3, 216-246.

Livezey, L.W. (Ed.) (2000), Faith in the City: Public Religion and Urban Transformation. (New York: New York University Press). 
Luttmer, E. (2005), "Neighbors as Negatives: Relative Earnings and Well-Being", The Quarterly Journal of Economics, 120, 963-1002.

McCleary, R. M. and Barro, R. J. (2006a), "Religion and Economy", Journal of Economic Perspectives, 20, 49-72.

McCleary, R. M. and Barro, R. J. (2006b), "Religion and Political Economy in an International Panel", Journal for the Scientific Study of Religion, 45, 149-175.

McClosky, D. (1976), "English Open Fields as Behavior towards Risk", Researches in Economic History, 1, 121-154.

McRoberts, O. M. (2003), Streets of glory: church and community in a black urban neighborhood (Chicago: University of Chicago Press).

Miller, A. S. and Hoffman, J. P. (1995), "Risk and Religion: An Explanation of Gender Differences in Religiosity", Journal for the Scientific Study of Religion, 34, 63-75.

Mississippi River Flood Control Association (1927), Losses and damages resulting from the flood of 1927, Mississippi River and tributaries, in the states of Illinois, Missouri, Kentucky, Tennessee, Arkansas, Mississippi and Louisiana. (Memphis, Tenn. Mississippi River Flood Control Association).

Moberg, D. O. (1984), The Church as a Social Institution: The Sociology of American Religion (Baker Book House, 2nd edition).

Overacker, I. (1998), The African American Church Community in Rochester, New York, 1900-1940 (University of Rochester, USA).

Pargament, K. I. (1997), The Psychology of Religion and Coping (Guilford Press, USA).

Parker, D. J. (2000), Floods. Vol. 1 (New York: Routledge).

Ramcharan, R. (2010), "Inequality and Redistribution: Evidence from U.S. Counties and States, 1890-1930", The Review of Economics and Statistics, 92, 729-744. 
Richardson, G. (2005), "The Prudent Village: Risk Pooling Institutions in Medieval English Agriculture", Journal of Economic History, 65, 386-413.

Roll, J. (2010), Spirit of Rebellion: Labor and Religion in the New Cotton South (University of Illinois Press, Urbana, Chicago, and Springfield).

Ronsvalle, J. and Ronsvalle, S. (1999), "Basic Trends in Religious Giving 1921-1995", in Chaves, M. and S. L. Miller (eds.) Financing American Religion (Walnut Creek, CA: Alta Mira Press).

Rosenzweig, M. R. (1988), "Risk, Implicit Contracts, and the Family in Rural Areas of Low Income Countries", The Economic Journal, 98, 1148-1170.

Rosenzweig, M. R. and Stark, O. (1989), "Consumption Smoothing, Migration, and Marriage: Evidence from Rural India", The Journal of Political Economy, 97, 905-926.

Ruggles, S., Alexander, T., Flood, S., Genadek, G., Schroeder, M. B., Trampe, B., Vick, R., and King, M. (2010), Integrated public use microdata series, current population survey: Version 3.0.[machine-readable database].

Scheve, K. and Stasavage, D. (2006), "Religion and preferences for social insurance", Quarterly Journal of Political Science, 1, 255-286.

Sernett, M. C. (1997), Bound For the Promised Land: African American Religion and the Great Migration (Durham, NC: Duke University Press).

Smith, T. W., Marsden, P., Hout, H. and Kim, J. (2013), General Social Surveys, 1972-2012 [machine readable data file]. (The Roper Center for Public Opinion Research, University of Connecticut).

Stark, R. (1992), "The Reliability of Historical United States Census Data on Religion", Sociological Analysis, 53, 91-95.

Steensland, B., Park, J. Z., Regnerus, M. D., Robinson, L. D., Wilcox, W. B., and Woodberry, R.D. (2000), "The Measure of American Religion: Toward Improving the State of the Art", Social Forces, 79, 291-318. 
Steinitz, L. Y. (1982), "The Local Church as Support for the Elderly", Journal of Gerontological Social Work, 4, 43-53.

Taylor, R. J. and Chatters, L. M. (1986), "Church-based Informal Support Among Elderly Blacks", The Gerontologist, 26, 637-642.

Taylor, R. J. and Chatters, L. M. (1988), "Church Members as a Source of Informal Social Support", Review of Religious Research, 30, 193-203.

Townsend, R. M. (1995), "Consumption Insurance: An Evaluation of Risk Bearing Systems in Low-Income Economies", Journal of Economic Perspectives, 9, 83-102.

Udry, C. (1994), "Risk and insurance in a rural credit market: an empirical investigation in northern Nigeria", Review of Economic Studies, 61, 251-269.

Valgren, V. N. (1928), "Developments and problems in farmers' mutual fire insurance", U.S. Department of Agriculture, Circular No. 54.

Weber, H. C. (1927), Presbyterian statistics through one hundred years, 1826-1926: tabulated, visualized and interpreted (Philadelphia: The General council, Presbyterian church in the U.S.A.).

White, G. F. (1945), Human Adjustment to Floods: A Geographical Approach to the Flood Problem in the United States (Chicago: University of Chicago Press).

Williamson, S. H. (2015), What Was the U.S. GDP Then? (MeasuringWorth).

Wuthnow, R. (2004), Saving America? Faith-based services and the future of civil society. (Princeton and Oxford: Princeton University Press). 
Figure 1a: The sample of flooded and non-flooded counties

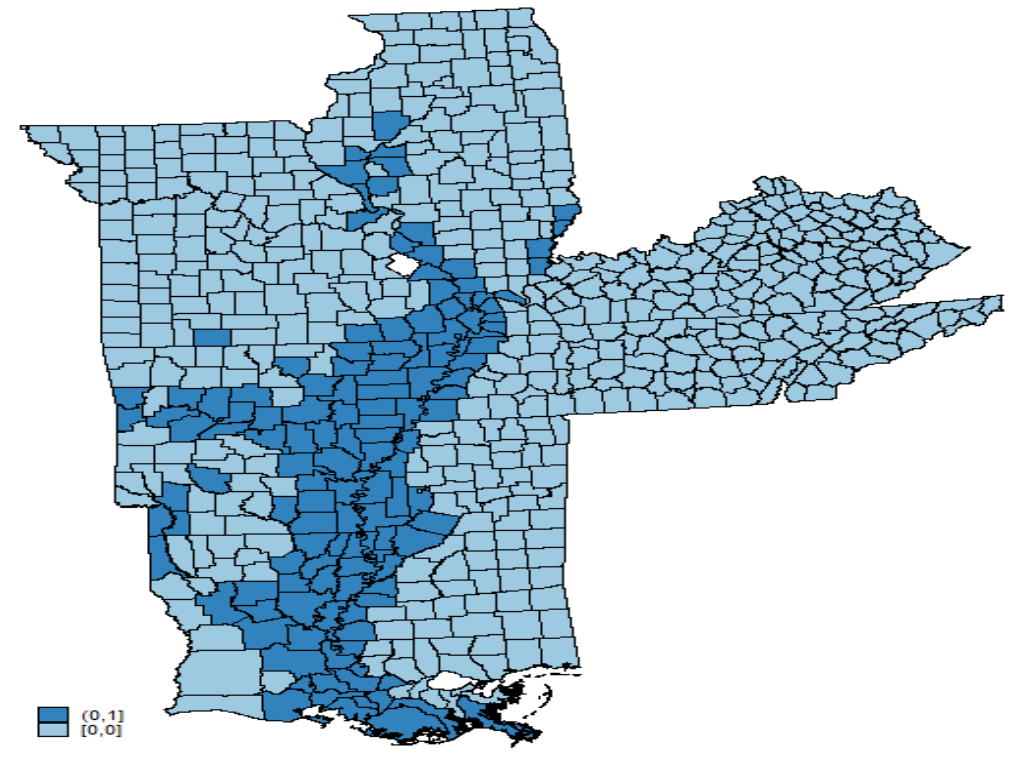

Figure 1b: Change in church membership rate between 1926 and 1936

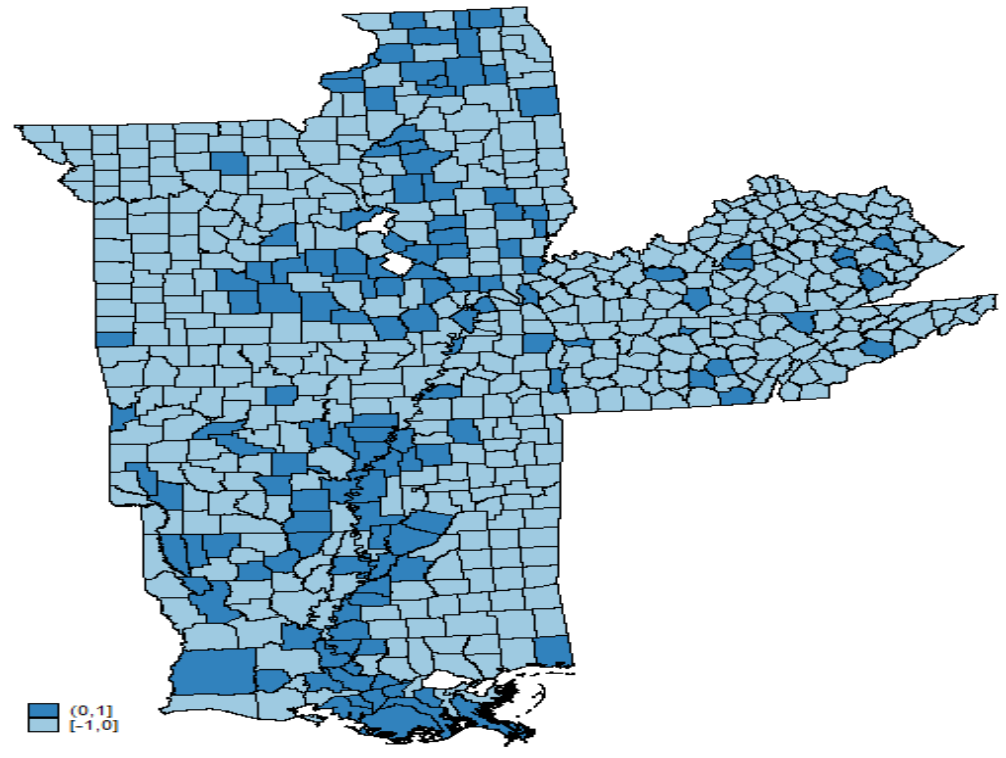


Figure 2: The relationship between the flood share and members per capita

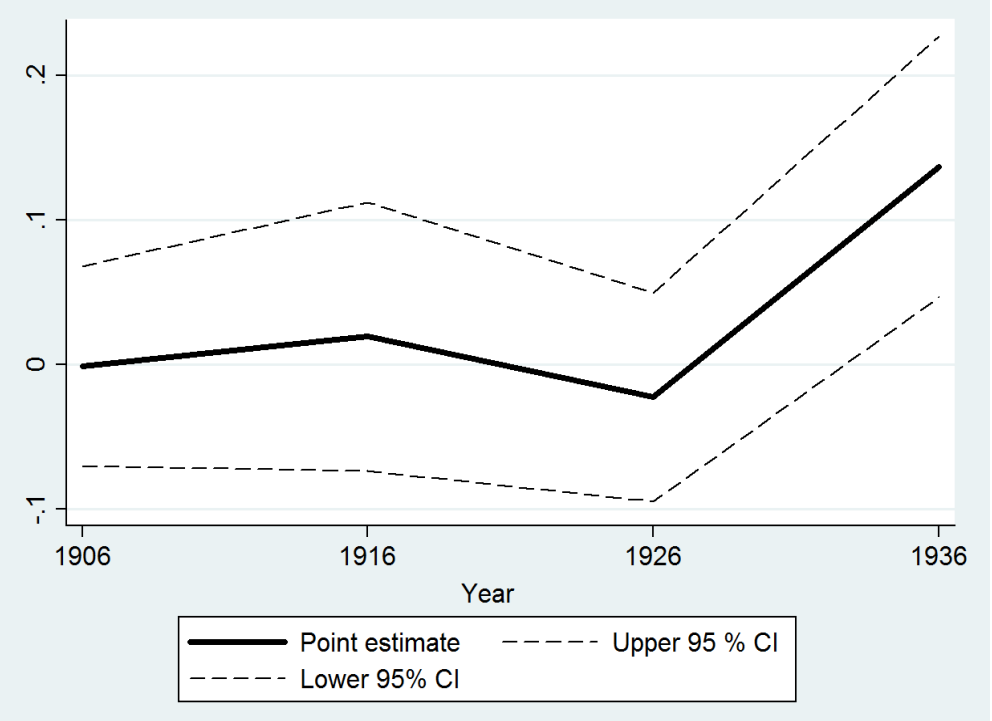

Note: The point estimates and 95\% CIs are from column 3 of Table 2 .

Figure 3: The partial relationship between Flood $_{c} \times I_{t}^{\text {post }}$ and members per capita

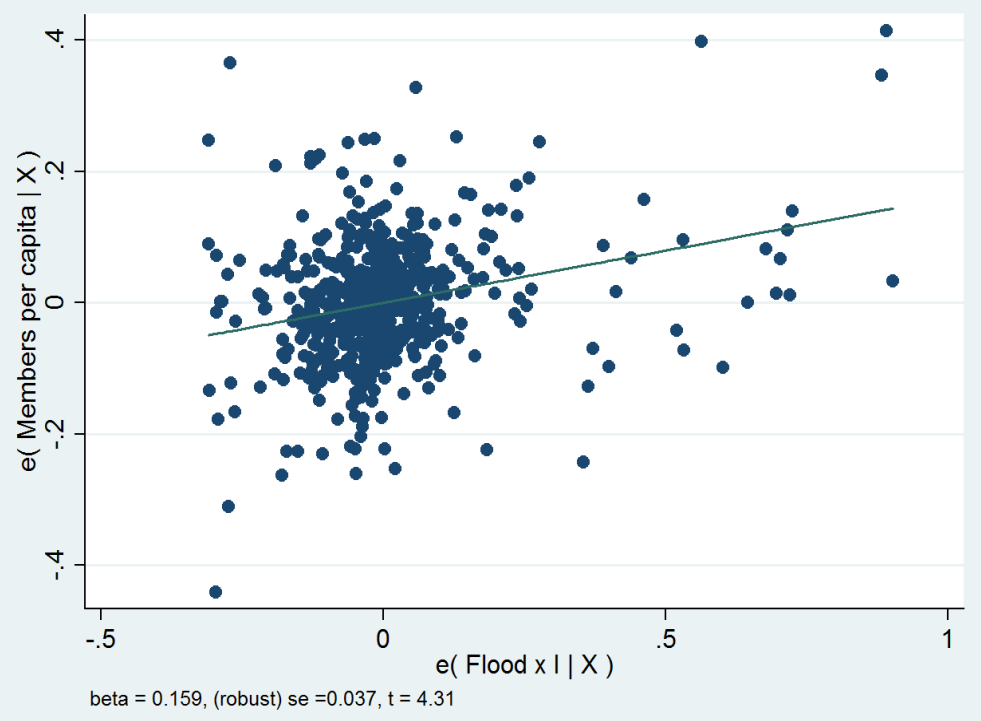

Note: The partial correlation plot is from column 3 of Table 3 
Figure 4: Evolution of ln Population in flooded and non-flooded counties over time

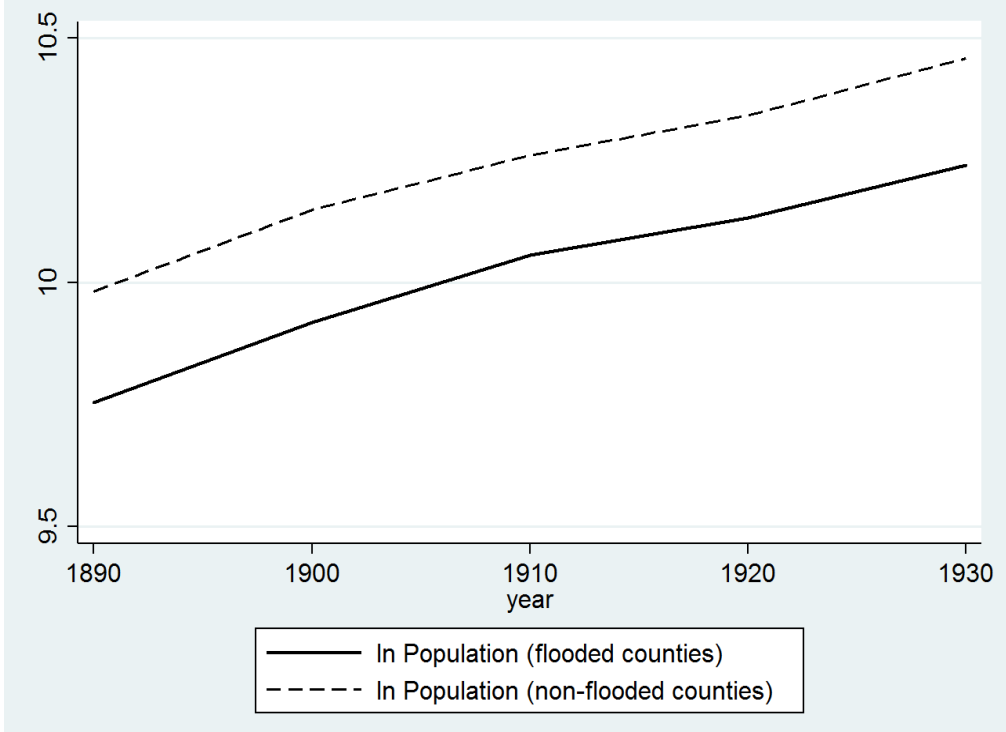

Figure 5: Evolution of ln Church Membership in flooded and non-flooded counties over time

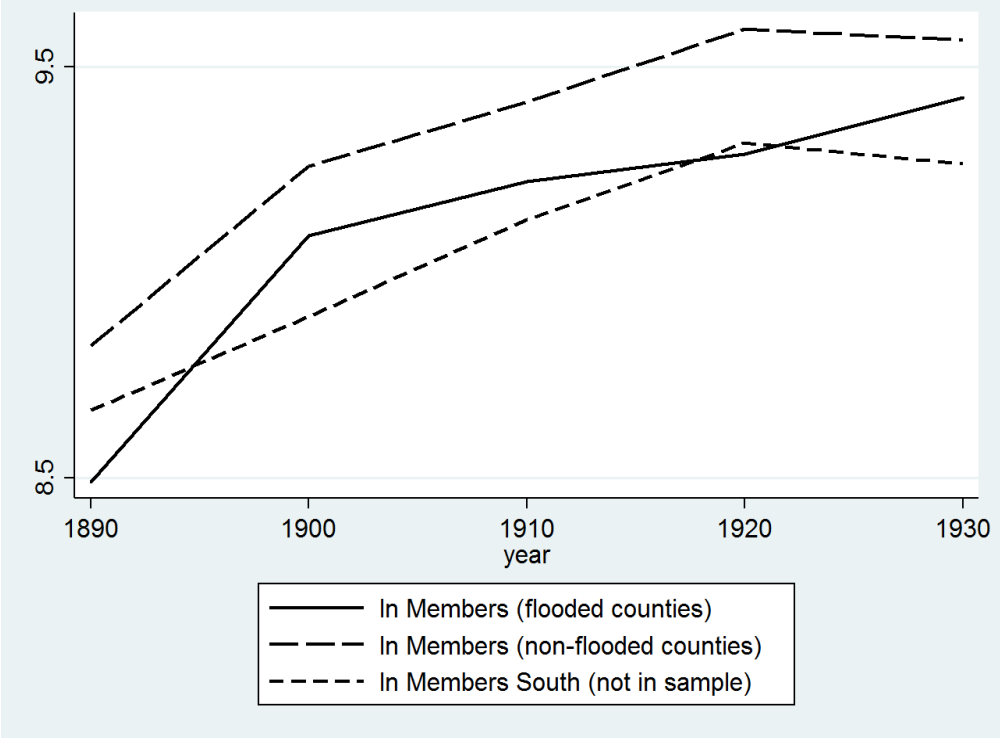


TABLE 1: SUMMARY STATISTICS

\begin{tabular}{|c|c|c|c|c|c|}
\hline & (1) & (2) & (3) & (4) & (5) \\
\hline VARIABLES & $\mathrm{N}$ & mean & sd & $\min$ & $\max$ \\
\hline Church members per capita & 1,276 & 0.376 & 0.141 & 0.0425 & 1.108 \\
\hline Log church members & 1,276 & 8.844 & 0.909 & 5.753 & 14.53 \\
\hline Flood $x 1^{\text {post }}$ & 1,276 & 0.0303 & 0.128 & 0 & 1 \\
\hline \multicolumn{6}{|l|}{ Controls $\left(\left.x\right|^{\text {post }}\right)$ : } \\
\hline Distance Mississippi River & 1,276 & 102,864 & 154,557 & 0 & 693,228 \\
\hline Cotton suitability & 1,276 & 0.226 & 0.343 & 0 & 1.327 \\
\hline Corn suitability & 1,276 & 4.640 & 5.404 & 0 & 15.12 \\
\hline Latitude & 1,276 & 18.10 & 18.22 & 0 & 42.26 \\
\hline Longitude & 1,276 & 44.52 & 44.60 & 0 & 95.30 \\
\hline Altitude range & 1,276 & 105.2 & 182.0 & 0 & 1,804 \\
\hline Altitude std & 1,276 & 17.02 & 30.70 & 0 & 335.0 \\
\hline Number of counties & 638 & 638 & 638 & 638 & 638 \\
\hline
\end{tabular}


Table 2: Flexible Estimates of the Flood-Membership Relation by Year, 1890--1936

$\begin{array}{lllll}(1) & \text { (2) (3) }\end{array}$

Dependent Variable:

(5)

(6)

Church members per capita

Log church members

\begin{tabular}{|c|c|c|c|c|c|c|}
\hline & & \\
\hline Flood x 1906 & $\begin{array}{c}0.107^{\star \star \star} \\
(0.0308) \\
{[0.030]}\end{array}$ & $\begin{array}{c}0.0458 \\
(0.0352) \\
{[0.0420]}\end{array}$ & $\begin{array}{c}-0.00101 \\
(0.0352) \\
{[0.0363]}\end{array}$ & $\begin{array}{c}0.369^{* * *} \\
(0.0970) \\
{[0.157]}\end{array}$ & $\begin{array}{c}0.159 \\
(0.127) \\
{[0.209]}\end{array}$ & $\begin{array}{l}0.0968 \\
(0.119) \\
{[0.182]}\end{array}$ \\
\hline Flood x 1916 & $\begin{array}{l}0.0701^{\star *} \\
(0.0342) \\
{[0.0424]}\end{array}$ & $\begin{array}{c}0.0483 \\
(0.0513) \\
{[0.0522]}\end{array}$ & $\begin{array}{c}0.0194 \\
(0.0473) \\
{[0.0467]}\end{array}$ & $\begin{array}{c}0.395^{\star \star \star} \\
(0.145) \\
{[0.170]}\end{array}$ & $\begin{array}{c}0.145 \\
(0.192) \\
{[0.224]}\end{array}$ & $\begin{array}{l}0.0575 \\
(0.181) \\
{[0.198]}\end{array}$ \\
\hline Flood x 1926 & $\begin{array}{c}0.0428 \\
(0.0290) \\
{[0.0286]}\end{array}$ & $\begin{array}{l}0.00555 \\
(0.0357) \\
{[0.0397]}\end{array}$ & $\begin{array}{l}-0.0224 \\
(0.0367) \\
{[0.0361]}\end{array}$ & $\begin{array}{c}0.428^{\star \star \star} \\
(0.125) \\
{[0.146]}\end{array}$ & $\begin{array}{l}0.106 \\
(0.161) \\
{[0.205]}\end{array}$ & $\begin{array}{l}0.0239 \\
(0.150) \\
{[0.179]}\end{array}$ \\
\hline Flood x 1936 & $\begin{array}{l}0.196^{\star * \star} \\
(0.0407) \\
{[0.0387]}\end{array}$ & $\begin{array}{c}0.169^{\star \star \star} \\
(0.0437) \\
{[0.0454]}\end{array}$ & $\begin{array}{l}0.137^{\star \star \star} \\
(0.0459) \\
{[0.0418]}\end{array}$ & $\begin{array}{c}0.895^{\star \star \star} \\
(0.155) \\
{[0.161]}\end{array}$ & $\begin{array}{c}0.507^{* *} \\
(0.199) \\
{[0.232]}\end{array}$ & $\begin{array}{l}0.344^{*} \\
(0.194) \\
{[0.200]}\end{array}$ \\
\hline \multicolumn{7}{|l|}{ Controls (x | $\left.\left.\right|^{\text {post }}\right)$ : } \\
\hline Latitude & No & No & Yes & No & No & Yes \\
\hline Longitude & No & No & Yes & No & No & Yes \\
\hline Cotton suitability & No & No & Yes & No & No & Yes \\
\hline Corn suitability & No & No & Yes & No & No & Yes \\
\hline Ruggedness & No & No & Yes & No & No & Yes \\
\hline Distance to Mississippi River & No & No & Yes & No & No & Yes \\
\hline Year FE & Yes & Yes & Yes & Yes & Yes & Yes \\
\hline State $x$ Year FE & No & Yes & Yes & No & Yes & Yes \\
\hline Observations & 3,185 & 3,185 & 3,185 & 3,185 & 3,185 & 3,185 \\
\hline R-squared & 0.231 & 0.292 & 0.325 & 0.416 & 0.474 & 0.504 \\
\hline Number of counties & 638 & 638 & 638 & 638 & 638 & 638 \\
\hline
\end{tabular}


Table 3: Baseline DD Estimates of the Effect of the Great Mississippi Flood on Membership

(1)

(2)
(4)

Dependent Variable:

Church members per capita

Log church members

\begin{tabular}{|c|c|c|c|c|c|c|}
\hline \multirow[t]{2}{*}{ Flood $x I^{\text {post }}$} & $\begin{array}{l}0.153^{* * *} \\
(0.0309)\end{array}$ & $\begin{array}{l}0.163^{\star * *} \\
(0.0343)\end{array}$ & $\begin{array}{l}0.159^{* * *} \\
(0.0368)\end{array}$ & $\begin{array}{l}0.467^{\star \star *} \\
(0.0760)\end{array}$ & $\begin{array}{l}0.401^{\star \star \star} \\
(0.0868)\end{array}$ & $\begin{array}{l}0.320^{* \star \star} \\
(0.0931)\end{array}$ \\
\hline & {$[0.0251]$} & [0.0242] & {$[0.0248]$} & [0.0497] & [0.0681] & {$[0.0609]$} \\
\hline
\end{tabular}

\section{Controls (x I ${ }^{\text {post }}$ ):}

Latitude

Longitude

Cotton suitability

Corn suitability

Ruggedness

Distance to Mississippi River

$\begin{array}{ll}\text { No } & \\ \text { No } & \\ \text { No } & \\ \text { No } & \text { No } \\ \text { No } & \text { No }\end{array}$

Year FE

State $x$ Year FE

$\begin{array}{lll}\text { Yes } & \text { Yes } & \text { Yes } \\ \text { No } & \text { Yes } & \text { Yes }\end{array}$

Yes
Yes
Yes
Yes
Yes
Yes
Yes
Yes

No
No
No
No
No
No

$\begin{array}{cccc}1,276 & 1,276 & 1,276 & 1,276 \\ 0.373 & 0.275 & 0.343 & 0.387 \\ 638 & 638 & 638 & 638\end{array}$

Observations

1,276

1,276

0.332

638

Yes

No

$\begin{array}{ll}\text { No } & \text { Yes } \\ \text { No } & \text { Yes } \\ \text { No } & \text { Yes } \\ \text { No } & \text { Yes } \\ \text { No } & \text { Yes } \\ \text { No } & \text { Yes }\end{array}$

Number of counties

638

638

638

$\begin{array}{cc}\text { Yes } & \text { Yes } \\ \text { Yes } & \text { Yes } \\ & \\ 1,276 & 1,276 \\ 0.343 & 0.387 \\ 638 & 638\end{array}$

Notes: Observations are reported at the county level over the period 1926-1936. The table reports least squares estimates weighted by county size. All regressions include county fixed effects. In columns (1)-(3), the outcome variable is church members per capita. In columns (4)-(6), the outcome variable is

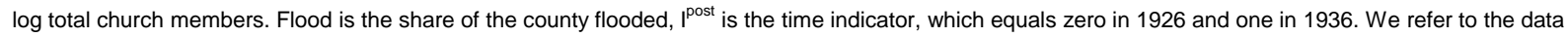
appendix for further details. Constants are not reported. Standard errors (in parentheses) account for arbitrary heteroskedasticity and are clustered at the county level $\left({ }^{* * *} p<0.01,{ }^{* *} p<0.05,{ }^{*} p<0.1\right)$. Conley standard errors with a spatial cutoff of 150 kilometers are reported in brackets. 
Table 4: Roubstness to Migration

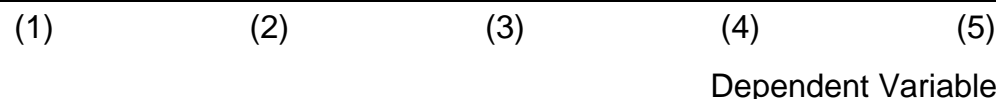

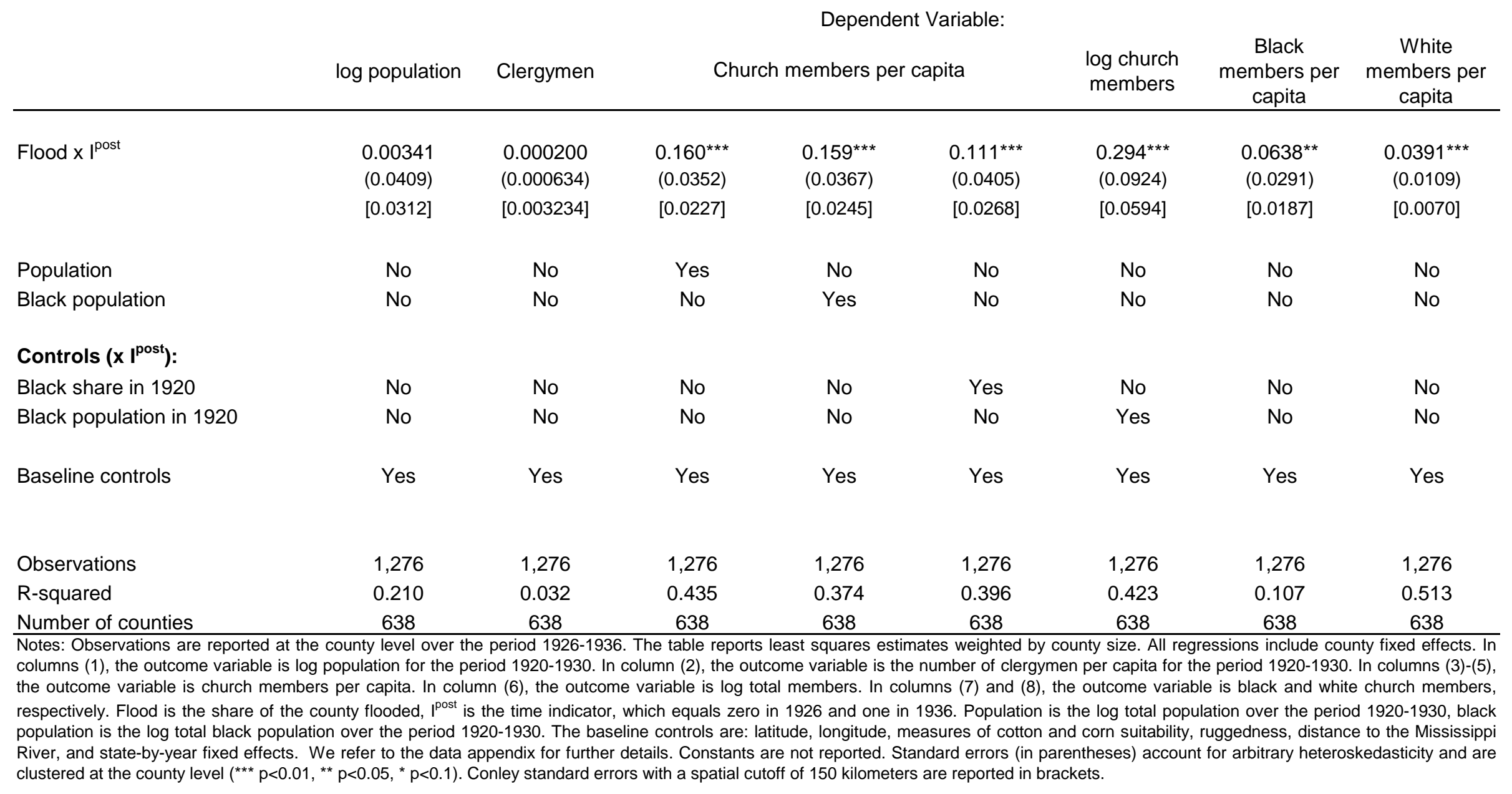


Table 5: Robustness to the New Deal and Redistribution

(1)

(2)

(3)

(4)

(5)

Dependent Variable:

Church members per capita

\begin{tabular}{|c|c|c|c|c|c|}
\hline \multirow[t]{2}{*}{ Flood $\left.x\right|^{\text {post }}$} & $\begin{array}{l}0.155^{\star \star *} \\
(0.0372)\end{array}$ & $\begin{array}{l}0.157^{* * *} \\
(0.0372)\end{array}$ & $\begin{array}{l}0.159^{\star * *} \\
(0.0374)\end{array}$ & $\begin{array}{l}0.151^{* * *} \\
(0.0369)\end{array}$ & $\begin{array}{l}0.148^{* * *} \\
(0.0375)\end{array}$ \\
\hline & {$[0.0250]$} & {$[0.0249]$} & {$[0.0254]$} & {$[0.0234]$} & {$[0.0240]$} \\
\hline Taxes per capita & Yes & No & No & No & No \\
\hline \multicolumn{6}{|l|}{ Controls $\left(\left.x\right|^{\text {post }}\right)$ : } \\
\hline Relief per capita & No & Yes & No & No & Yes \\
\hline Public works per capita & No & No & Yes & No & Yes \\
\hline AAA spendings per capita & No & No & No & Yes & Yes \\
\hline Baseline controls & Yes & Yes & Yes & Yes & Yes \\
\hline Observations & 1,240 & 1,275 & 1,273 & 1,272 & 1,270 \\
\hline R-squared & 0.370 & 0.380 & 0.376 & 0.374 & 0.381 \\
\hline Number of counties & 636 & 638 & 638 & 638 & 638 \\
\hline \multicolumn{6}{|c|}{$\begin{array}{l}\text { Notes: Observations are reported at the county level over the period 1926-1936. The table reports least squares estimates weighted } \\
\text { by county size. All regressions include county fixed effects. The outcome variable is church members per capita. Flood is the share }\end{array}$} \\
\hline \multicolumn{6}{|c|}{$\begin{array}{l}\text { of the county flooded, } p^{\text {post }} \text { is the time indicator, which equals zero in } 1926 \text { and one in } 1936 \text {. Taxes per capita is the county level of } \\
\text { log total taxes per capita over ther period } 1920-1930 \text {. The New Deal variables are: log relief per capita, log public works per capita, } \\
\text { and log AAA spendings per capita. The baseline controls are: latitude, longitude, measures of cotton and corn suitability, } \\
\text { ruggedness, distance to the Mississippi River, and state-by-year fixed effects. We refer to the data appendix for further details. } \\
\text { Constants are not reported. Standard errors (in parentheses) account for arbitrary heteroskedasticity and are clustered at the county } \\
\text { level }\left({ }^{\star * \star} p<0.01,{ }^{\star *} p<0.05,{ }^{\star} p<0.1\right) \text {. Conley standard errors with a spatial cutoff of } 150 \text { kilometers are reported in brackets. }\end{array}$} \\
\hline
\end{tabular}


Table 6: Economic Distress as a Mechanism

(1)

(2)

(3)

Dependent Variable:

Church members per capita

Log church members

Log damage per 1,000

inhabitants

\begin{tabular}{|c|c|c|c|}
\hline \multirow[t]{2}{*}{ Damage } & $\begin{array}{c}0.00831^{* * *} \\
(0.00188)\end{array}$ & $\begin{array}{c}0.0235^{\star * *} \\
(0.00456)\end{array}$ & \\
\hline & {$[0.00181]$} & {$[0.00431]$} & \\
\hline Flood $\left.x\right|^{\text {post }}$ & & & $\begin{array}{c}10.30 * * * \\
(0.738) \\
{[0.727]}\end{array}$ \\
\hline Baseline controls & Yes & Yes & Yes \\
\hline Observations & 1,276 & 1,276 & 1,276 \\
\hline R-squared & 0.364 & 0.403 & 0.698 \\
\hline Number of counties & 638 & 638 & 638 \\
\hline \multicolumn{4}{|c|}{$\begin{array}{l}\text { Notes: Observations are reported at the county level over the period 1926-1936. The table reports least squares estimates } \\
\text { weighted by county size. All regressions include county fixed effects. The outcome variable is church members per capita } \\
\text { (column } 1 \text { ), log church members (column 2), and log damage per } 1,000 \text { inhabitants in } 1927 \text { (column } 3 \text { ). Flood is the share of } \\
\text { the county flooded, post is the time indicator, which equals zero in } 1926 \text { and one in } 1936 \text {. Damage is the log total property } \\
\text { damage per } 1,000 \text { inhabitants by reasons of the Great Mississippi Flood in } 1927 \text {. The baseline controls are: latitude, longitude, } \\
\text { measures of cotton and corn suitability, ruggedness, distance to the Mississippi River, and state-by-year fixed effects. We refer } \\
\text { to the data appendix for further details. Constants are not reported. Standard errors (in parentheses) account for arbitrary } \\
\text { heteroskedasticity and are clustered at the county level }\left({ }^{* *} p<0.01,{ }^{* *} p<0.05,{ }^{*} p<0.1 \text { ). Conley standard errors with a spatial }\right. \\
\text { cutoff of } 150 \text { kilometers are reported in brackets. }\end{array}$} \\
\hline
\end{tabular}


Table 7: Credit Constraints as a Mechansim

(1)

(2)

(3)

(4)

Dependent Variable:

Church members per capita

\begin{tabular}{|c|c|c|c|c|}
\hline \multirow[t]{3}{*}{ Flood $\times I^{\text {post }}$} & $0.265^{\star \star *}$ & $0.250^{* * *}$ & $0.205^{\star \star *}$ & $0.261^{* \star *}$ \\
\hline & $(0.0740)$ & $(0.0758)$ & $(0.0563)$ & $(0.0611)$ \\
\hline & {$[0.0537]$} & {$[0.0568]$} & {$[0.0481]$} & {$[0.0456]$} \\
\hline \multirow[t]{3}{*}{ Flood $x I^{\text {post }} \times$ Banks } & $-0.587^{\star \star}$ & $-0.574^{\star \star}$ & & \\
\hline & $(0.286)$ & $(0.280)$ & & \\
\hline & {$[0.195]$} & {$[0.196]$} & & \\
\hline \multirow[t]{3}{*}{ Flood $\times I^{\text {post }} \times$ Deposits } & & & -0.520 & $-1.847^{\star \star \star}$ \\
\hline & & & $(0.437)$ & $(0.603)$ \\
\hline & & & {$[0.356]$} & {$[0.420]$} \\
\hline \multirow[t]{3}{*}{ Flood $x I^{\text {post }} x$ Urban } & & 0.168 & & $0.824^{\star * *}$ \\
\hline & & $(0.248)$ & & $(0.267)$ \\
\hline & & & & {$[0.171]$} \\
\hline Baseline controls & Yes & Yes & Yes & Yes \\
\hline Observations & 1,276 & 1,276 & 1,276 & 1,276 \\
\hline R-squared & 0.382 & 0.384 & 0.376 & 0.393 \\
\hline Number of counties & 638 & 638 & 638 & 638 \\
\hline \multicolumn{5}{|c|}{$\begin{array}{l}\text { Notes: Observations are reported at the county level over the period } 1926-1936 \text {. The table reports least squares estimates weighted by county size. All } \\
\text { regressions include county fixed effects. The outcome variable is church members per capita. Flood is the share of the county flooded, }{ }^{\text {post }} \text { is the time } \\
\text { indicator, which equals zero in } 1926 \text { and one in } 1936 \text {. Banks are the number of banks per } 1,000 \text { inhabitants in the county in } 1926 \text {. Deposits are the total } \\
\text { value of deposits (in thousands of dollars) per } 1,000 \text { inhabitants in } 1926 \text {. Urban is the urbanization share in the county in } 1920 \text {. The baseline controls are: } \\
\text { latitude, longitude, measures of cotton and corn suitability, ruggedness, distance to the Mississippi River, and state-by-year fixed effects. We refer to the data } \\
\text { appendix for further details. Constants are not reported. Standard errors (in parentheses) account for arbitrary heteroskedasticity and are clustered at the } \\
\text { county level }\left({ }^{\star \star \star} p<0.01,{ }^{* \star} p<0.05,{ }^{\star} p<0.1\right) \text {. Conley standard errors with a spatial cutoff of } 150 \text { kilometers are reported in brackets. }\end{array}$} \\
\hline
\end{tabular}


Dependent Variable:

Fundamental members

per capita
Fundamental members per total members

\begin{tabular}{|c|c|c|}
\hline Flood $x$ I post $^{\text {plo }}$ & $\begin{array}{l}0.102^{* * *} \\
(0.0309) \\
{[0.0194]}\end{array}$ & $\begin{array}{c}0.0610^{\star *} \\
(0.0293) \\
{[0.0179]}\end{array}$ \\
\hline Baseline controls & Yes & Yes \\
\hline Observations & 1,276 & 1,276 \\
\hline R-squared & 0.260 & 0.122 \\
\hline Number of counties & 638 & 638 \\
\hline \multicolumn{3}{|c|}{$\begin{array}{l}\text { Notes: Observations are reported at the county level over the period 1926-1936. The table reports least squares estimates weighted } \\
\text { by county size. All regressions include county fixed effects. In column (1), the outcome variable is fundamental church members per } \\
\text { capita. In column (2), the outcome variable is fundamental church members out of total members. Flood is the share of the county } \\
\text { flooded, } I^{\text {post }} \text { is the time indicator, which equals zero in } 1926 \text { and one in } 1936 \text {. The baseline controls are: latitude, longitude, } \\
\text { measures of cotton and corn suitability, ruggedness, distance to the Mississippi River, and state-by-year fixed effects. We refer to the } \\
\text { data appendix for further details. Constants are not reported. Standard errors (in parentheses) account for arbitrary } \\
\text { heteroskedasticity and are clustered at the county level }\left({ }^{\star \star *} p<0.01,{ }^{\star \star} p<0.05,{ }^{*} p<0.1\right) \text {. Conley standard errors with a spatial cutoff of } \\
150 \text { kilometers are reported in brackets. }\end{array}$} \\
\hline
\end{tabular}


Table 9: Charity, Insurance, and Strictness as a Mechanism

\section{(1) \\ (2) \\ Dependent Variable:}

(3)

(4)

Church members per capita

Flood $\left.x\right|^{\text {post }} \mathrm{x}$ :

$\begin{array}{ll}\text { Charity Index } & 0.0118^{* * *} \\ (0.00424)\end{array}$

Network Index

Fundamentalism Index

County-by-year FE

Denomintion-by-year FE

Observations

Counties

Denominations

Yes
$0.0109^{* * *}$

(0.00266)

$0.00188^{\star \star \star}$

$(0.000579)$

$0.00237^{\star * *}$

$(0.000640)$

$0.00930^{* * *}$

$0.00781^{* * *}$

$(0.00138)$

(0.00102)

Yes

Yes

Yes

Yes

Yes

63,800

638

50

\section{3,800}

638

50
63,800

638

Notes: Observations are reported at the denomination-by-county level over ther period 1926-1936. The table reports least squares estimates weighted by county size. All regressions include county-by-year fixed effects and denomination-by-year fixed effects. The outcome variable is church members relative to population by denomination. Flood is the share of the county flooded, $I^{\text {post }}$ is the time indicator, which equals zero in 1926 and one in 1936 (absorbed by the county-by-year fixed effects). The following denomination-specific indices (charity index, network index, and fundamentalism index) Index ${ }_{d}^{j}$ are interacted with Flood $x I^{\text {post }}$. For a detailed explanation of the indices, see Section 5.2. We also refer to the data appendix for further details. Constants are not reported. Standard errors (in parentheses) account for arbitrary heteroskedasticity and are clustered at the county level $\left({ }^{* \star *} p<0.01,{ }^{* *} p<0.05,{ }^{*} p<0.1\right)$. 


\section{Online Appendix}

\section{Data Appendix}

\section{Religion Data}

Church Membership: The Census of Religious Bodies collected and published information on church members for the years 1890, 1906, 1916, 1926, and 1936. We use two measures of church membership at the county level: (i) church members per capita (the denominator is the county population of either 1890, 1900, 1910, 1920, or 1930) and (ii) total church members. The Census of the Religious Bodies in 1926 and 1936 also collected information on church members by denomination and race allowing us to construct separate measures of church membership by race (see Table 4). We consider denominations as black (white) if their members were listed as exclusively black (white); see the Census of Religious Bodies (Bureau of the Census, Table 33, 1930; 1941) for further details. County-level church membership refers to all religious denominations listed in the Census of Religious Bodies. Source: ICPSR 2896 file (Haines, 2010).

Clergymen: We use the microdata from IPUMS (Ruggles et al., 2010) to obtain a measure of clergymen per capita for the years 1920 and 1930. This variable is constructed as the number of clergymen (IPUMS variable OCC1950==9) divided by county population. We refer to the description of the IPUMS variable "OCC1950" for further details.

Denomination Specific Indices: Data for the charity indices are from the Census of Religious Bodies in 1936 and for the network indices from the Census of Religious Bodies in 1926. The classification scheme for the fundamentalist index follows Steensland et al. (2000). We refer to Section 5.2 for further details.

\section{Geography Data}

Flood: Flood intensity is based on the official report of the relief operations of the American Red Cross (1929, Appendix Table VI) (1929). Source: Replication files of Hornbeck and Naidu (2014). 
Suitability of Cotton and Corn: Data on cotton (corn) suitability come from the FAO (2012), which calculates cotton (corn) suitability as the maximum potential yield of cotton (corn) based on climate, soil type, and ideal growing conditions for cotton (corn); for more information see Hornbeck and Naidu (2014, footnote 22). Source: Replication files of Hornbeck and Naidu (2014).

Distance to the Mississippi River: Distance in meters from the Mississippi River to a county's centroid. The measure is based on the GIS Map of the National Weather Service (Rivers of the US), http://www.nws.noaa.gov/geodata/catalog/hydro/html/rivers.htm.

Longitude and Latitude: Data on the longitude and latitude of each county seat are retrieved from Fishback et al. (2011).

Ruggedness: Measures of counties' ruggedness are based on the USGS National Elevation Dataset (Farr et al., 2007). Like Hornbeck and Naidu (2014), we use the standard deviation in altitude across county points and the maximum range in altitude across county points as proxies for ruggedness. Source: Replication files of Hornbeck and Naidu (2014).

\section{County Level Controls}

Damage: County-level data on the economic losses and damages per 1,000 inhabitants from the Great Mississippi Flood of 1927 are from the Mississippi River Flood Control Association (1927). The data are reported as total property damage by county in 1927 US dollars.

New Deal: County-level data on the New Deal spending program (AAA, public works, relief) per capita are from Fishback et al. (2005).

Taxes per Capita: County-level data on per capita tax revenues for the years 1920 and 1930 are from Ramcharan (2010).

Banks: The number of banks at the county level in 1926 are from the FDIC Data on Banks in the United States. Source: ICPSR 7 file (Federal Deposit Insurance Corporation, 2001).

Deposits: Total value of deposits (in thousands of dollars) in 1926 are from the FDIC Data on Banks in the United States. Source: ICPSR 7 file (Federal Deposit Insurance Corporation, 2001). 


\section{Appendix Tables and Figures}

Table A1: Test for Outliers

(1)

(3)

(4)

Dependent Variable:

Church members per capita Log church members

\begin{tabular}{lcccc} 
Percentiles excluded: & $1 \& 99$ & $5 \& 95$ & $1 \& 99$ & $5 \& 95$ \\
\hline Flood $\times$ I $^{\text {post }}$ & $\begin{array}{c}0.138^{\star \star *} \\
(0.0375)\end{array}$ & $\begin{array}{c}0.0984^{\star \star \star} \\
(0.0376)\end{array}$ & $\begin{array}{c}0.320^{\star \star *} \\
(0.0933)\end{array}$ & $\begin{array}{c}0.347^{\star \star *} \\
(0.0995)\end{array}$ \\
Baseline controls & Yes & Yes & Yes & Yes \\
& & & & \\
Observations & 1,236 & 1,090 & 1,244 & 1,122 \\
R-squared & 0.379 & 0.397 & 0.381 & 0.399 \\
Number of counties & 618 & 545 & 622 & 561
\end{tabular}

Notes: Observations are reported at the county level over the period 1926-1936. The table reports least squares estimates weighted by county size. All regressions include county fixed effects. In columns (1) and (2), the outcome variable is church members per capita. In columns (3) and (4), the outcome variable is log total church members. Flood is the share of the county flooded, $I^{\text {post }}$ is the time indicator, which equals zero in 1926 and one in 1936. Columns (1) and (3) exclude counties with the outcomes in the 1st and 99th percentiles. Columns (2) and (4) exclude counties with the outcomes in the 5th and 95th percentiles. The baseline controls are: latitude, longitude, cotton and corn suitability, ruggedness, distance to MS, and state-by-year fixed effect. We refer to the data appendix for further details. Constants are not reported. Standard errors (in parentheses) account for arbitrary heteroskedasticity and are clustered at the county level $\left({ }^{* * *} p<0.01,{ }^{* *} p<0.05,{ }^{*} p<0.1\right)$. 
Table A2: Sample Modifications

(1) (2) (3) (4)

Dependent Variable:

Church Members per capita

\begin{tabular}{|c|c|c|c|c|c|}
\hline & $\begin{array}{c}\text { Distance to MS } \\
\text { River } 50 \mathrm{~km}\end{array}$ & $\begin{array}{c}\text { Distance to MS } \\
\text { River } 75 \mathrm{~km}\end{array}$ & $\begin{array}{c}\text { Distance to MS } \\
\text { River } 100 \mathrm{~km}\end{array}$ & $\begin{array}{c}\text { Adjacent control } \\
\text { counties }\end{array}$ & $\begin{array}{c}\text { Restricted sample of } \\
163 \text { Counties }\end{array}$ \\
\hline Flood $\left.x\right|^{\text {post }}$ & $\begin{array}{l}0.104^{* * *} \\
(0.0390)\end{array}$ & $\begin{array}{l}0.129^{* * *} \\
(0.0381)\end{array}$ & $\begin{array}{l}0.127^{* * *} \\
(0.0383)\end{array}$ & $\begin{array}{l}0.120^{\star * *} \\
(0.0355)\end{array}$ & $\begin{array}{l}0.0920^{* *} \\
(0.0428)\end{array}$ \\
\hline Baseline controls & Yes & Yes & Yes & Yes & Yes \\
\hline Observations & 352 & 424 & 474 & 518 & 326 \\
\hline R-squared & 0.242 & 0.257 & 0.205 & 0.243 & 0.438 \\
\hline Number of counties & 176 & 212 & 237 & 259 & 163 \\
\hline
\end{tabular}

Notes: Observations are reported at the county level over the period 1926-1936. The table reports least squares estimates weighted by county size. All regressions include county fixed effects. In columns (1)-(3) we restrict the control counties to be not further than $50 \mathrm{~km} / 75 \mathrm{~km} / 100 \mathrm{~km}$ from the Mississippi river. Column (4) only uses control counties that are adjacent to the flooded region. Column (5) considers the 163 counties used in the study of Hornbeck and Naidu (2014). The outcome variable is church members per capita. Flood is the share of the county flooded, $\mathrm{I}^{\text {post }}$ is the time indicator, which equals zero in 1926 and one in 1936. The baseline controls are: latitude, longitude, cotton and corn suitability, ruggedness, distance to MS, and state-by-year fixed effect. We refer to the data appendix for further details. Constants are not reported. Standard errors (in parentheses) account for arbitrary heteroskedasticity and are clustered at the county level $\left({ }^{* * *} p<0.01,{ }^{* *} p<0.05,{ }^{*} p<0.1\right)$. 
Dependent Variable:

Church members per capita
Log church members

\begin{tabular}{|c|c|c|}
\hline Flood $\left.x\right|^{\text {post }}$ & $\begin{array}{c}0.146^{\star \star \star} \\
(0.0366)\end{array}$ & $\begin{array}{c}0.296^{\star \star \star} \\
(0.111)\end{array}$ \\
\hline Baseline controls & Yes & Yes \\
\hline Observations & 1,276 & 1,276 \\
\hline R-squared & 0.238 & 0.227 \\
\hline Number of counties & 638 & 638 \\
\hline \multicolumn{3}{|c|}{$\begin{array}{l}\text { Notes: Observations are reported at the county level over the period } 1926-1936 \text {. The table reports least squares estimates weighted } \\
\text { by county size. All regressions include county fixed effects. The outcome variables are } 1 \text { ) church members per capita excluding } \\
\text { members of the Southern Baptist Church and the Methodist Episcopal Church (South) 2) total church members excluding the same } \\
\text { churches. Flood is the share of the county flooded, }{ }^{\text {post }} \text { is the time indicator, which equals zero in } 1926 \text { and one in } 1936 \text {. The } \\
\text { geographic controls are: latitude, Iongitude, cotton and corn suitability, ruggedness, and distance to MS. We refer to the data } \\
\text { appendix for further details. Constants are not reported. Standard errors (in parentheses) account for arbitrary heteroskedasticity and } \\
\text { are clustered at the county level }\left({ }^{* \star \star} p<0.01,{ }^{\star \star} p<0.05,{ }^{*} p<0.1\right) \text {. }\end{array}$} \\
\hline
\end{tabular}


Table A4: Placebo Treatment Period

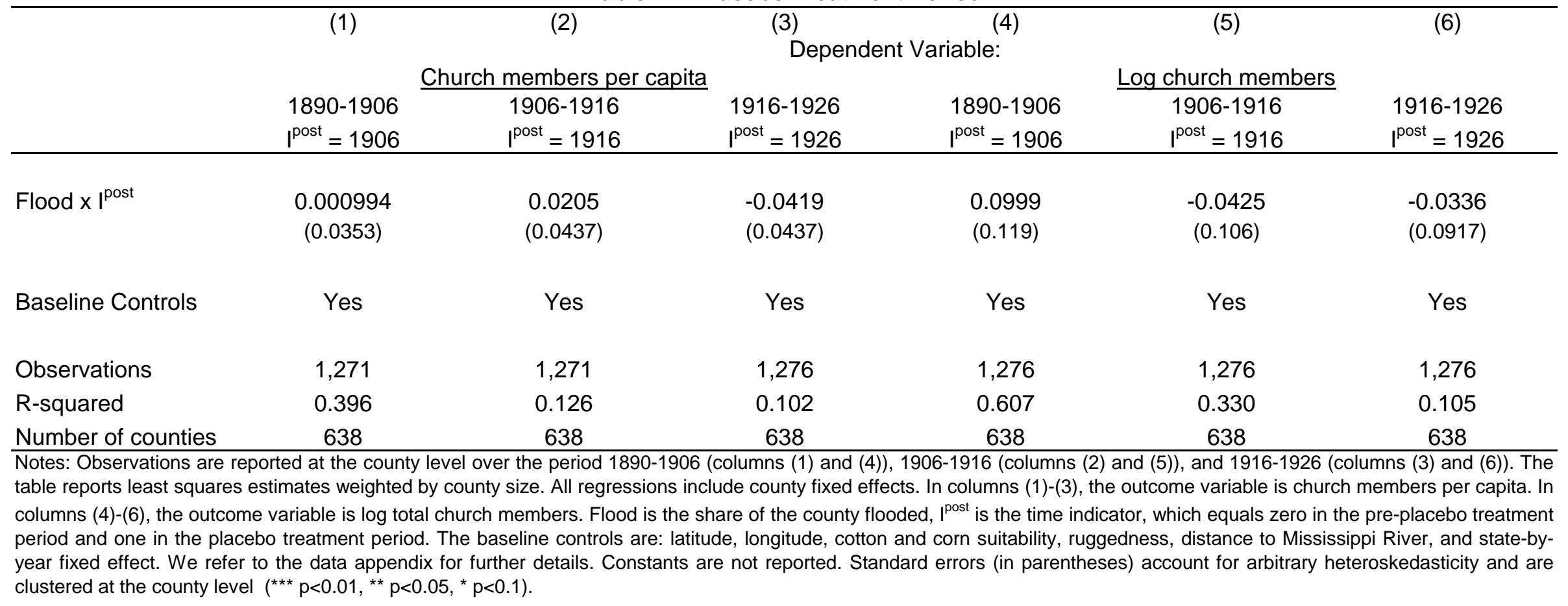


Dependent Variable:

Church members per capita
Log church members

$\begin{array}{lcc}\text { Flood } \times \text { I post }^{0.154^{* * *}} & 0.310^{* * *} \\ & (0.0372) & (0.0924) \\ \text { Baseline Controls } & \text { Yes } & \text { Yes } \\ \text { Nationality Shares in } 1920 \times \mathrm{I}^{\text {post }} & \text { Yes } & \text { Yes } \\ & & \\ \text { Observations } & 1,276 & 1,276 \\ \text { R-squared } & 0.407 & 0.468 \\ \text { Number of counties } & 638 & 638\end{array}$

Notes: Observations are reported at the county level over the period 1926-1936. The table reports least squares estimates weighted by county size. All regressions include county fixed effects. In column (1), the outcome variable is church members per capita. In column (2), the outcome variable is log total church members. Flood is the share of the county flooded, Ipost is the time indicator, which equals zero in 1926 and one in 1936 . Nationality shares in 1920 are interacted with the time indicator, $I^{\text {post }}$. The baseline controls are: latitude, longitude, measures of cotton and corn suitability, ruggedness, distance to the Mississippi River, and state-byyear fixed effects. We refer to the data appendix for further details. Constants are not reported. Standard errors (in parentheses) account for arbitrary heteroskedasticity and are clustered at the county level $\left({ }^{\star \star *} p<0.01,{ }^{\star \star} p<0.05,{ }^{*} p<0.1\right)$. 
Appendix Figure 1: Mutual Fire Insurance in the United States 1926

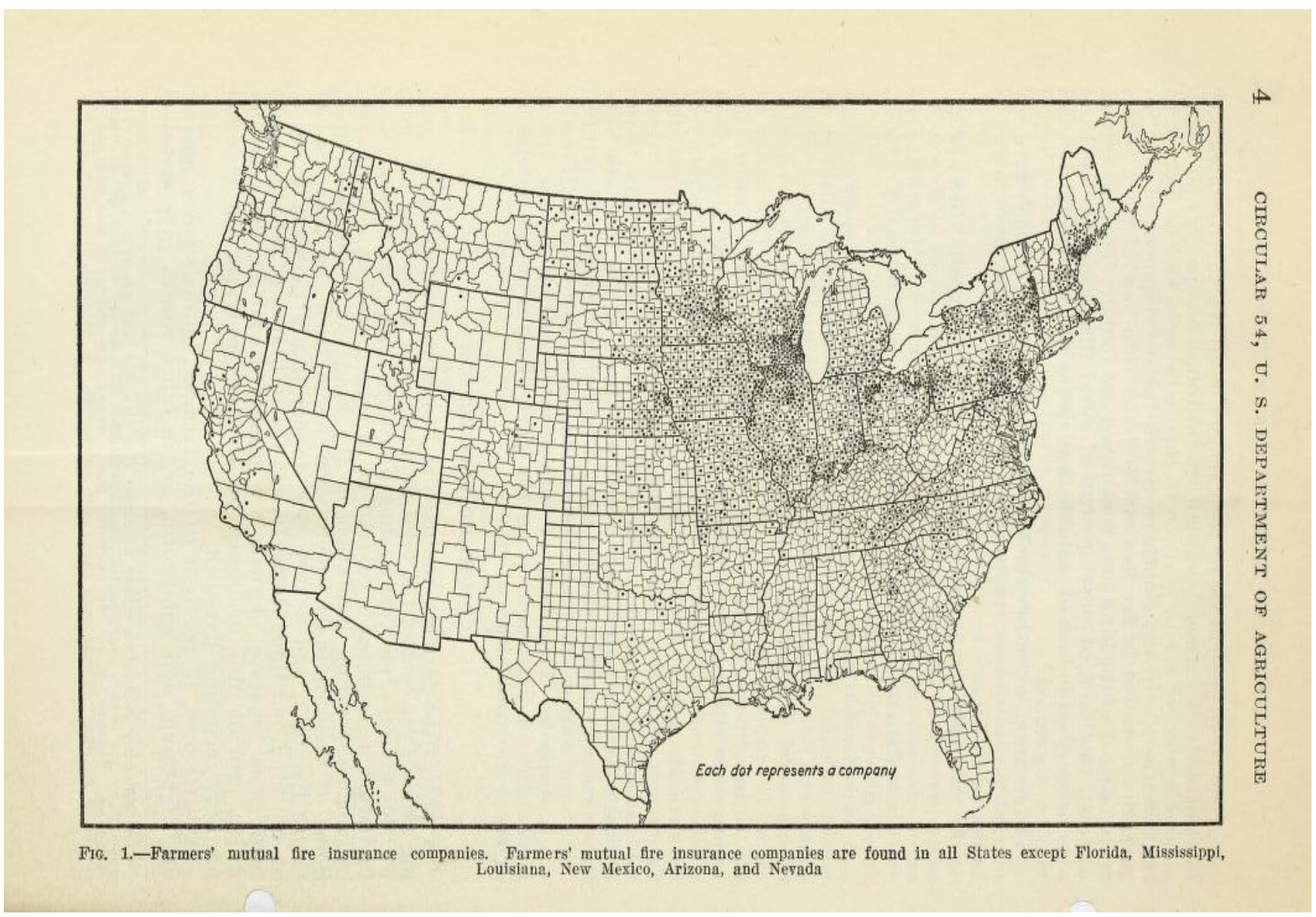

Source: Valgren, V. L. (1928, p.4). "Developments and problems in farmers' mutual fire insurance." U.S. Department of Agriculture, Circular No 54. 